\title{
Drought resistance increases from the individual to the ecosystem level in highly diverse Neotropical rainforest: a meta-analysis of leaf, tree and ecosystem responses to drought
}

\author{
Thomas Janssen $^{1}$, Katrin Fleischer ${ }^{2}$, Sebastiaan Luyssaert ${ }^{3}$, Kim Naudts $^{1}$, and Han Dolman ${ }^{1}$ \\ ${ }^{1}$ Department of Earth Sciences, Vrije Universiteit Amsterdam, Amsterdam, the Netherlands \\ ${ }^{2}$ Land Surface-Atmosphere Interactions, Technical University of Munich, Freising, Germany \\ ${ }^{3}$ Department of Ecological Science, Vrije Universiteit Amsterdam, Amsterdam, the Netherlands
}

Correspondence: Thomas Janssen (t.a.j.janssen@vu.nl)

Received: 20 December 2019 - Discussion started: 8 January 2020

Revised: 6 April 2020 - Accepted: 20 April 2020 - Published: 15 May 2020

\begin{abstract}
The effects of future warming and drying on tropical forest functioning remain largely unresolved. Here, we conduct a meta-analysis of observed drought responses in Neotropical humid forests, focusing on carbon and water exchange. Measures of leaf-, tree- and ecosystem-scale performance were retrieved from 145 published studies conducted across 232 sites in Neotropical forests. Differentiating between seasonal and episodic drought, we find that (1) during seasonal drought the increase in atmospheric evaporative demand and a decrease in soil matric potential result in a decline in leaf water potential, stomatal conductance, leaf photosynthesis and stem diameter growth while leaf litterfall and leaf flushing increase. (2) During episodic drought, we observe a further decline in stomatal conductance, photosynthesis, stem growth and, in contrast to seasonal drought, a decline also in daily tree transpiration. Responses of ecosystem-scale processes, productivity and evapotranspiration are of a smaller magnitude and often not significant. Furthermore, we find that the magnitude and direction of a drought-induced change in photosynthesis, stomatal conductance and transpiration reported in a study is correlated to study-averaged wood density. Although wood density is often not functionally related to plant hydraulic properties, we find that it is a good proxy for hydraulic behaviour and can be used to predict leaf- and tree-scale responses to drought. We present new insights into the functioning of tropical forest in response to drought and present novel relationships between wood density and tropical-tree responses to drought.
\end{abstract}

\section{Introduction}

The Neotropical rainforests of South and Central America, with the Amazon basin at its centre, cover the largest tract of tropical forest on Earth. As such, these forests are a crucial component of the regional and global climate system as a source of convective heat and moisture, driving atmospheric moisture transport and precipitation patterns (Poveda and Salazar, 2004; Zemp et al., 2014). General circulation models project that South and Central America will warm by 2 to $5^{\circ} \mathrm{C}$ in the coming decades under the business as usual emission scenario (Marengo et al., 2010). Furthermore, seasonal drought is expected to become more severe (Boisier et al., 2015; Malhi et al., 2009; Marengo et al., 2010). Undisturbed old growth forest in the Amazon basin has increased in above-ground biomass since the 1980s, acting as a substantial sink of atmospheric carbon (Feldpausch et al., 2016; Phillips et al., 2009). However, recent drought events appear to have at least temporarily reversed the Amazon carbon sink through reduced productivity (Gatti et al., 2014; Yang et al., 2018b), elevated tree mortality (Feldpausch et al., 2016; Phillips et al., 2009) and increased emissions from fire (Aragão et al., 2018; Van Der Laan-Luijkx et al., 2015; Van Der Werf et al., 2008). Furthermore, the integrity of Neotropical forests may be threatened by unforeseen feedback mechanisms triggered by drought and deforestation (Khanna et al., 2017; Zemp et al., 2017). These vegetation-atmosphere feedbacks can reduce atmospheric moisture recycling and increase carbon emissions, which further amplify forest loss and global climate change (Cox et al., 2000, 2004; David- 
son et al., 2012; Erfanian et al., 2017; Exbrayat et al., 2017; Malhi et al., 2009).

Despite the critical role of Neotropical forests in driving future climate scenarios, there are large uncertainties surrounding the sensitivity of these forests to drought. Uncertainties are partly the result of the biological diversity found in Neotropical forests as the magnitude and direction of a response to drought is found to be strongly dependent on the species measured (Bonal et al., 2000a; Domingues et al., 2014). Also, uncertainties arise as droughts differ in length, periodicity and severity (Bonal et al., 2016; Marengo et al., 2011; Meir et al., 2018). Finally, ecophysiological responses to drought occur on a multitude of spatial and temporal scales. These responses range from the almost instant closure of the stomata on a single leaf to large-scale tree mortality that has persistent effects on many ecosystem processes (Brando et al., 2008; Rowland et al., 2015a, b). Currently, there is no quantitative overview of how Neotropical forests respond to different intensities of drought, from the leaf level up to the entire ecosystem level. Below we formulate three key issues that guide our meta-analysis.

\subsection{What types of drought occur in Neotropical forests?}

Here, we differentiate three types of drought that differ in periodicity and severity: seasonal drought, episodic drought and multi-year drought. Seasonality in precipitation is widespread in Neotropical forests. Tropical humid forests loose roughly $100 \mathrm{~mm}$ of water every month through evapotranspiration (da Rocha et al., 2004; Shuttleworth, 1988). Months receiving less than $100 \mathrm{~mm}$ of rainfall will thus result in a precipitation deficit; these months are generally referred to as dry season months (Aragão et al., 2007; Sombroek, 2001). Seasonal droughts are by definition periodic, and trees are generally found to be adapted to such a seasonal decline in precipitation (Brando et al., 2010; Goulden et al., 2004; Hutyra et al., 2007).

Episodic droughts, on the other hand, are caused by anomalous climatic conditions, primarily those imposed by strong El Niño-Southern Oscillation (ENSO) and tropical North Atlantic sea surface temperature anomalies (Marengo et al., 2011). In the neotropics, episodic droughts often coincide with record-breaking air temperatures (Jiménez-Muñoz et al., 2016; Lee et al., 2013; Panisset et al., 2017). Elevated air temperature can directly impact plant function through physiological heat stress (Doughty, 2011; Doughty and Goulden, 2009a), but it also drives a non-linear increase in atmospheric vapour pressure deficit (VPD). This increase in evaporative demand during drought can amplify drought conditions through increased evapotranspiration, accelerating soil drying (Jung et al., 2010) and increasing the risk of hydraulic failure (Mcdowell et al., 2008). The amplification of plant drought stress during episodic drought through the interaction of soil drying, high air temperatures and evapora- tive demand has been termed "hotter droughts" (Allen et al., 2015; Breshears et al., 2013), and these hotter droughts are expected to become more frequent and severe with climate change.

Multi-year droughts are defined as a more permanent reduction in precipitation spanning years to decades. Longterm records of river discharge and oxygen isotopes in tree rings indicate that Neotropical forests experienced several multi-year droughts in the 20th century, notably in the $1960 \mathrm{~s}$ (Brienen et al., 2012; Marengo et al., 2011; Richey et al., 1989). To date, the effect of prolonged rainfall reduction on leaf, tree and ecosystem functioning have only experimentally been assessed in two throughfall exclusion experiments at Tapajós and Caxiuanã in the eastern Amazon (Fisher et al., 2006; Meir et al., 2009; Nepstad, 2002). The results from the Tapajós and Caxiuanã experiments have been previously synthesized (e.g. Meir et al., 2009, 2018; da Costa et al., 2010), and much of our knowledge about leaf-, tree- and ecosystem-scale responses to multi-year droughts in tropical forests originates from these experiments. Therefore, and because of the low number of replicates (i.e. two) of such experiments, this meta-analysis will focus only on the effects of seasonal and episodic drought on leaf, tree and ecosystem functioning.

\subsection{How is drought impacting leaf-, tree- and ecosystem-scale processes?}

On the leaf scale, seasonal and episodic drought are often found to result in a downregulation of stomatal conductance, the ease with which $\mathrm{CO}_{2}$ and water vapour can diffuse between the atmosphere and the leaf intercellular spaces through the stomates (Hogan et al., 1995; Huc et al., 1994). The most recent evidence suggests that stomates progressively close in response to a decline in leaf water potential ( $\psi_{1}$; Buckley, 2019; Choat et al., 2018; Drake et al., 2017; Martin-StPaul et al., 2017). Here, we focus specifically on how drought-induced changes in $\psi_{1}$, the water potential gradient and the different conductances along the hydraulic pathway are driving the observed drought-induced changes in productivity and transpiration. During steady-state transpiration, transpiration at the leaf level $\left(\mathrm{mol} \mathrm{H}_{2} \mathrm{O} \mathrm{m}^{-2} \mathrm{~s}^{-1}\right)$ is given by

$E=G_{\mathrm{c}} \frac{\mathrm{VPD}}{P}$

where $G_{\mathrm{c}}$ is the leaf-area-specific crown conductance to water vapour (mol $\mathrm{H}_{2} \mathrm{O} \mathrm{m}^{-2} \mathrm{~s}^{-1}$ ), VPD is the atmospheric vapour pressure deficit $(\mathrm{kPa})$ and $P$ is the atmospheric pressure $(\mathrm{kPa})$. The crown conductance itself can be calculated using the resistance subtraction method:

$$
G_{\mathrm{c}}=\frac{1}{\left(1 / g_{\mathrm{s}}+1 / g_{\mathrm{b}}\right)},
$$

where $g_{\mathrm{s}}$ is the stomatal and $g_{\mathrm{b}}$ the boundary layer conductance to water vapour $\left(\mathrm{mol} \mathrm{H}_{2} \mathrm{O} \mathrm{m}^{-2} \mathrm{~s}^{-1}\right)$. Similar to leaf 
transpiration, the transpiration flow through the tree can be described by

$J=k_{\mathrm{sl}}\left(\psi_{\mathrm{s}}-\psi_{1}\right)$,

where $J$ is the sapwood-area-specific transpiration rate (i.e. sap flux density; $\mathrm{g} \mathrm{H}_{2} \mathrm{O} \mathrm{m}^{-2} \mathrm{~s}^{-1}$ ), $k_{\mathrm{sl}}$ the sapwood-area-specific soil-to-leaf hydraulic conductance $\left(\mathrm{g} \mathrm{H}_{2} \mathrm{O} \mathrm{m}^{-2} \mathrm{MPa}^{-1} \mathrm{~s}^{-1}\right)$ and $\psi_{\mathrm{s}}$ the soil water potential in the root zone (MPa). During steady-state transpiration, the flow of water through the tree equals the transpiration from the total leaf surface area of the tree so that

$J=E \times M_{\mathrm{w}} \frac{A_{1}}{A_{\mathrm{s}}}$,

where $M_{\mathrm{W}}$ is the molar mass of water $\left(\sim 18 \mathrm{~g} \mathrm{~mol}^{-1}\right)$ and $A_{1}$ and $A_{\mathrm{s}}$ are the total leaf and sapwood area $\left(\mathrm{m}^{2}\right)$ of the tree, respectively. Equation (1) describes the vapour-phase transport of water through the leaf stomates from the leaf to the atmosphere, while Eq. (3) describes the liquid-phase water transport from the root to the leaf through the xylem sapwood. During drought, $k_{\mathrm{sl}}$ declines sharply as a result of the reduced hydraulic conductance of a drier soil as well as of a reduced hydraulic conductance of the xylem as a result of xylem embolism (e.g. Fisher et al., 2006). It follows that the decline in $k_{\mathrm{sl}}$ should be balanced by a decline in $G_{\mathrm{c}}$ that is achieved by progressive stomatal closure (Meinzer et al., 1995). Nonetheless, Eqs. (1) and (3) also show that transpiration can stay the same or increase or decrease during drought, depending on whether a decline in $k_{\mathrm{sl}}$ and $G_{\mathrm{c}}$ is compensated for by an increase in the water potential gradient $\left(\psi_{\mathrm{s}}-\psi_{1}\right)$ or evaporative demand (VPD).

Progressive stomatal closure constrains not only transpiration but also the diffusion of $\mathrm{CO}_{2}$ into the leaf, limiting leaf photosynthesis. In Neotropical humid forests, the stomatal conductance response to drought is generally larger than the decline in leaf photosynthesis, resulting in an increase in intrinsic water use efficiency (iWUE; Bonal et al., 2000a; Santos et al., 2018). It is unclear how leaf-scale processes respond to drought in Neotropical humid forest, with some studies reporting strong reductions in stomatal conductance, transpiration and photosynthesis during seasonal and episodic drought (e.g. Hogan et al., 1995a; Huc et al., 1994; Sendall et al., 2009; Wolfe et al., 2016) while others report no significant change in stomatal conductance and photosynthesis and even an increase in transpiration (e.g. Allen and Pearcy, 2000; Domingues et al., 2014; Fisher et al., 2006).

Leaf-scale responses to drought can propagate to the tree scale, with reduced growth of the stem and new leaves, increased leaf shedding and litterfall, and reduced daily tree transpiration (Brum et al., 2018; Doughty et al., 2015; Fontes et al., 2018; Hofhansl et al., 2014; Phillips et al., 2009). Furthermore, the combined drought response of all individual trees in the ecosystem contributes to the observed ecosystemscale response to drought. Reduced leaf photosynthesis and leaf and stem growth can result in a decline in gross primary productivity (GPP) and consequently a decline in net primary productivity (NPP), while reduced daily tree transpiration might result in a decline in ecosystem evapotranspiration. Moreover, increased leaf litterfall in response to drought can boost microbial respiration and result in an increase in ecosystem respiration (Sayer et al., 2007). However, soil respiration is limited by temperature and moisture in Neotropical humid forests and is found to decline with a dry season decline in soil moisture (Chambers et al., 2004; Sotta et al., 2004; Zanchi et al., 2014). The integration and synthesis of the observed drought responses on the leaf, tree and ecosystem scale have not been carried out but are critical to highlight current knowledge gaps.

\subsection{Can hydraulic behaviour explain differences in drought responses among species and studies?}

Different tree species show markedly different responses to drought, both on the leaf level (Bonal et al., 2000a; Domingues et al., 2014) and the individual tree level (Esquivel-Muelbert et al., 2017a, b; Phillips et al., 2009). The magnitude and direction of observed drought responses depend on the hydraulic behaviour of the particular species measured in that study (Bonal et al., 2000a; Fisher et al., 2006; Machado and Tyree, 1994). For example, species can adopt different drought avoidance and tolerance strategies (Volaire, 2018). Drought avoidance strategies aim to avoid a dangerous decline in $\psi_{1}$ that could lead to significant xylem embolism and thus damage the hydraulic pathway. Maintaining a stable high $\psi_{1}$ during drought can be achieved by strict stomatal control on transpiration (Huc et al., 1994; Machado and Tyree, 1994), increasing deep-soil-water uptake (Bonal et al., 2000b; Brum et al., 2019) and maintaining high plant internal water storage and conductance (Tyree et al., 2003; Wolfe, 2017), and through leaf shedding (Wolfe et al., 2016). Conversely, drought tolerance strategies imply that low leaf and xylem water potentials are tolerated without significant and irreversible embolism-induced losses of hydraulic function (Maréchaux et al., 2015; Markesteijn et al., 2011a; Tyree et al., 2003).

Tree hydraulic behaviour is strongly dependent on the characteristics of the xylem sapwood (Janssen et al., 2020; Markesteijn et al., 2011a, b; Meinzer et al., 2008a, b; Wolfe, 2017). Species that do not avoid dehydration through stomatal closure are generally found to have xylem that is highly resistant to embolism, thus making them drought tolerant (Skelton et al., 2015; Vogt, 2001). Conversely, droughtavoiding species are able to buffer declines in xylem water potential by using water that is stored in the sapwood (i.e. capacitance) and by strong stomatal control on transpiration (Borchert, 1994; Machado and Tyree, 1994; Meinzer et al., 2008b). In Neotropical tree species, sapwood capacitance and conductivity decline while embolism resistance generally increases with increasing wood density (De Guz- 
man et al., 2017; Janssen et al., 2020; Meinzer et al., 2008b; Santiago et al., 2018). This suggests that low-wood-density species can be considered drought avoiders, while highwood-density tree species are characterized as drought tolerant. Wood density is often not functionally related to the specific hydraulic properties (conductivity, capacitance and embolism resistance) that are driving hydraulic behaviour (Janssen et al., 2020; Lachenbruch and Mcculloh, 2014). Nonetheless, wood density is an easily interpretable and widely available plant trait and therefore a useful proxy to compare different studies in which more specific hydraulic properties and traits were not measured. Therefore, we will use wood density as a proxy for hydraulic behaviour in this meta-analysis and examine whether differences in studyaveraged wood density explain the variability in observed leaf- and tree-scale responses to drought between different studies.

\section{Methods}

\subsection{Data collection}

The data collection focused on published observations from the lowland humid forests of the neotropics, roughly between $20^{\circ} \mathrm{S}$ and $20^{\circ} \mathrm{N}$ (Fig. 1a). We searched the Web of Science for literature published between 1979 and 2019. This time frame matches the ERA5 reanalysis climate data (ECMWF, 2019) that were used to obtain harmonized meta-data for the retrieved literature. Publications were archived in a database if they contained one of the following variables: stomatal conductance, leaf photosynthesis, leaf water potential, stem sap flux density, daily tree transpiration, stem diameter increment, leaf flushing, leaf litterfall, ecosystem evapotranspiration, gross primary productivity, net primary productivity, ecosystem respiration and net ecosystem productivity. For studies that reported at least one of these variables, the observed values were stored in a database containing the reported value, the location, and the month and year in which the measurement took place. For leaf-scale measurements, all data included in the database were originally measured at midday (around 12:00 LT (local time)), except for predawn leaf water potential which was measured just before sunrise (around 06:00 LT). Site-measured soil matric potential was also included in the database. If possible, the leaf- and tree-scale variables of individual trees including genus and species name were stored in the database. Otherwise, site averages were used. Observations of ecosystem-scale processes always consisted of site averages.

For every site in the database, the site biome was extracted from the "Terrestrial Ecoregions of the World" map from the World Wide Fund for Nature (Olson et al., 2001). Sites that were not located in the "Tropical and subtropical moist broadleaf forest" biome were omitted from the meta-analysis. Furthermore, the site elevation was extracted from the ALOS global $30 \mathrm{~m}$ digital surface model (Tadono et al., 2016), which was aggregated to a $1 \mathrm{~km}$ resolution using Google Earth Engine. All sites that were located at elevations higher than $1000 \mathrm{~m}$ a.s.l. were regarded as montane environments and were as such omitted from the meta-analysis. The final database used for the meta-analysis included observed drought responses from 145 published studies conducted across 232 sites in Neotropical humid forests (Tables S1 and S2 in the Supplement).

Monthly averaged values of soil water content, air temperature and dew point air temperature at $2 \mathrm{~m}$ above the surface were retrieved from the ERA5 reanalysis product at a $0.25^{\circ}$ horizontal resolution $(\sim 28 \mathrm{~km}$; ECMWF, 2019). Values were retrieved for all the sites from January 1979 to August 2019. Monthly averaged air temperature and dew point temperature at four hourly averages (15:0018:00 UTC) were used to retrieve monthly averaged midday $(12: 00 \mathrm{LT})$ temperature and dew point temperature in the four time zones covering the study area. These values were used to calculate monthly averaged midday vapour pressure deficit (VPD) following Buck (1981). The ERA5-retrieved monthly averaged midday VPD corresponded well with the monthly averaged midday VPD that was measured at nine meteorological towers across the study area (Fig. S1 in the Supplement).

\subsection{Data preprocessing and deriving additional variables}

From the collected leaf, tree and ecosystem variables, we derived additional variables of transpiration, productivity and water use efficiency. On the leaf level, we calculated the instantaneous intrinsic water use efficiency (iWUE; $\mu \mathrm{mol} \mathrm{mol}{ }^{-1}$ ) at midday directly from the published data as

$\mathrm{iWUE}=\frac{A}{g_{\mathrm{s}}}$,

where $A$ is the midday leaf-area-specific photosynthesis rate $\left(\mu \mathrm{mol} \mathrm{CO} \mathrm{m}^{-2} \mathrm{~s}^{-1}\right.$ ) and $g_{\mathrm{s}}$ is the leaf-area-specific stomatal conductance to water vapour $\left(\mathrm{mol} \mathrm{H}_{2} \mathrm{O} \mathrm{m}^{-2} \mathrm{~s}^{-1}\right)$. On the tree scale, we calculated the instantaneous sapwood-area-specific soil-to-leaf hydraulic conductance $\left(\mathrm{kg} \mathrm{dm}^{-2} \mathrm{MPa}^{-1} \mathrm{~s}^{-1}\right)$ following Love and Sperry (2018):

$k_{\mathrm{sl}}=\frac{J_{\mathrm{max}}}{\left(\psi_{\mathrm{lpd}}-\psi_{\mathrm{lmd}}\right)}$,

where $J_{\max }$ is the daily maximum sap flux density $\left(\mathrm{kg} \mathrm{dm}^{-2} \mathrm{~s}^{-1}\right), \psi_{\text {lmd }}$ is the midday leaf water potential (MPa) and $\psi_{\mathrm{lpd}}$ is the predawn leaf water potential (MPa). Predawn $\psi_{1}$ is measured before the onset of leaf transpiration and considered a proxy for $\psi_{\mathrm{s}}$ in the root zone. Therefore, the difference between midday $\psi_{1}$ and predawn $\psi_{1}$ is regarded as a proxy for the midday water potential gradient within the tree, from the root up to the canopy (Eq. 3). Finally, 

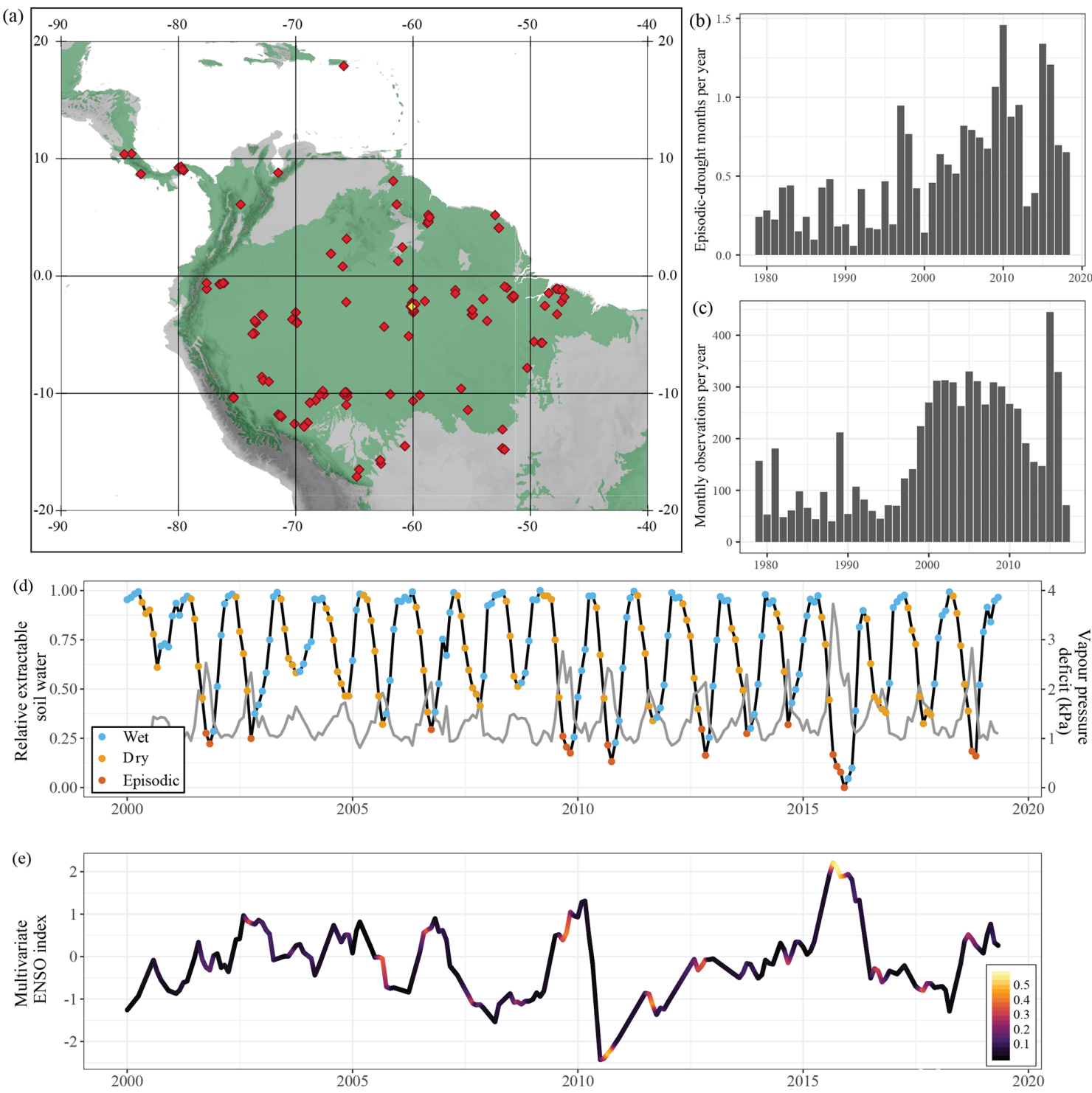

Figure 1. Summary of the database. Site locations (a), average number of episodic-drought months per year (b) and number of monthly observations in the database per year (c). The map shows the locations of the 229 Neotropical forest sites from which data were used in this meta-analysis. In green is the distribution of tropical and subtropical moist broadleaf forest from the "Terrestrial Ecoregions of the World" map (Olson et al., 2001). The average number of episodic-drought months per year (b) was calculated as the average number of months classified as episodic drought per year recorded at all sites, independent of whether we have field data for these months. Below, a monthly time series of relative extractable water (light grey) and vapour pressure deficit (dark grey) for the K34 site in the central Amazon (d) is indicated in yellow on the map (a). The coloured dots indicate whether that specific month was classified as a wet season, dry season or episodic-drought month. (e) A time series of the multivariate ENSO index with positive values indicating El Niño (dry) conditions and negative values La Niña (wet) conditions. The colouring of the ENSO index represents the number of episodic-drought months recorded per month across the sites in the database, ranging from 0 (no droughts recorded) to 0.58 (episodic drought in $58 \%$ of the plots).

we calculated leaf-area-specific midday crown conductance $\left(\mathrm{mol} \mathrm{H}_{2} \mathrm{O} \mathrm{m}^{-2} \mathrm{~s}^{-1}\right.$ ) following Meinzer et al. (1997):

$G_{\mathrm{c}}=\frac{J_{\max }\left(\frac{A_{\mathrm{s}}}{A_{\mathrm{l}}}\right) P}{\mathrm{VPD}}$,

where $J_{\max }$ is the daily maximum sap flux density but now in moles $\left(\mathrm{mol} \mathrm{m}^{-2} \mathrm{~s}^{-1}\right) ; A_{\mathrm{s}} / A_{1}$ is the sapwood area to leaf area ratio; $P$ is atmospheric pressure, which was set to one standard atmosphere (101.325 $\mathrm{kPa})$; and VPD is the monthly averaged midday vapour pressure deficit derived from ERA5 data.

On the ecosystem scale, the total net primary productivity (NPP) and above-ground NPP (ANPP) were calculated as the sum of stem growth and canopy growth and for NPP also root 
growth (sensu Doughty et al., 2015; Hofhansl et al., 2014). Finally, the ecosystem water use efficiency was calculated as the ratio between gross primary productivity (GPP) and ecosystem evapotranspiration (sensu Yang et al., 2016).

To be able to compare drought responses of daily tree transpiration and ecosystem evapotranspiration with transpiration estimates based solely on observations performed on the leaf scale, we estimated potential midday leaf-area-specific transpiration $\left(\mathrm{mol} \mathrm{m}^{-2} \mathrm{~s}^{-1}\right)$ as

$E_{\mathrm{pot}}=g_{\mathrm{s}} \frac{\mathrm{VPD}}{P}$,

where $g_{\mathrm{s}}$ is the midday leaf-area-specific stomatal conductance to water vapour and VPD is the monthly averaged midday VPD $(\mathrm{kPa})$ derived from the ERA5 reanalysis data. In this estimation we use only the stomatal conductance and not the boundary layer conductance (Eqs. 1,2), the two of which are often decoupled in large leaves and dense tropical forest canopies (Jarvis and Mcnaughton, 1986; De Kauwe et al., 2017; Meinzer et al., 1997). Using only stomatal conductance and not the total crown conductance likely causes a gross overestimation of absolute leaf transpiration, and these estimates should never be used as a measure of actual leaf transpiration. Therefore, we only use potential leaf-scale transpiration in this meta-analysis to compare transpiration responses among different plant hydraulic strategies and omit this variable from the general analysis.

Many studies that measured sap flux density reported either the maximum daily sap flux density or the integrated daily sap flux density (daily transpiration). In 14 out of 34 studies that reported sap flux density results present in our database, only the maximum midday sap flux density values were reported and not the daily transpiration rates. As we find that maximum sap flux density and daily tree transpiration show a strong linear relationship in the studies included in our database (Fig. S2), the sapwood-area-specific daily transpiration for these studies was estimated as

$J_{\text {daily }}=24\left(\frac{J_{\max }}{a}\right)$,

where $J_{\max }$ is the daily maximum sap flux density and $a$ is a parameter fitted using a linear regression between maximum sap flux density and daily transpiration (Fig. S2). Parameter $a$ is essentially a factor describing the difference between $J_{\max }$ and daily average $J$.

\subsection{Dry season and drought definition}

As the dry season progresses, soil moisture content, relative extractable soil water (REW) and soil matric potential decline as daily evapotranspiration surpasses precipitation (see e.g. Wright et al., 1992; Nepstad, 2002). The occurrence of rain at the end of the dry season generally results in a rapid increase in soil matric potential and a relief from plant water stress (Fontes et al., 2018; Roberts et al., 1990; Tobin et al.,
1999). Therefore, we define dry season months as months in which REW is reduced relative to the previous month (Fig. 1d). The REW is the amount of soil water available for plant uptake, which is often expressed as the volumetric soil moisture scaled between field capacity $(\mathrm{REW}=1)$ and permanent wilting point $(\mathrm{REW}=0)$. However, as there are insufficient measurements to construct reliable soil water retention curves across the study sites, we could not calculate REW. Instead, we estimated a pseudo REW as the normalized integrated soil moisture from ERA5, with 0 in the driest month and 1 in the wettest month of the entire time series (1979-2019) at that specific site (Figs. 1, 2). Monthly integrated soil moisture over the entire soil profile was calculated as the weighted average of soil moisture content in all four soil layers $(0-1.89 \mathrm{~m}$ below the surface) provided in the ERA5 product. In Neotropical humid forest, the bulk soil water is taken up from the first $1.3 \mathrm{~m}$ of soil, but this can extend up to $10-12 \mathrm{~m}$ during drought (Brum et al., 2019; Davidson et al., 2011). To avoid a rapid oscillation of dry and wet season months over time due to small reductions or increases in REW, we labelled initially classified single dry season months in between 2 wet season months as wet season, and vice versa. We find that, despite the uncertainties in ERA5 soil moisture data due to the underlying data assimilation and modelling, the ERA5-derived REW is able to accurately capture the seasonality of site-measured soil matric potential $\left(R^{2}=0.5, p<0.001\right.$; Fig. S3) and wet season-dry season oscillations (Fig. 1d).

Dry season months where REW was lower than the $10 \%$ quantile of REW in all dry season months were labelled as episodic-drought months (Fig. 1d). The 10\% episodic-drought threshold value was chosen as a reasonably strict episodic-drought definition while still yielding a large enough sample size for the statistical analysis to differentiate between episodic drought and a regular dry season. We also performed a sensitivity analysis for this drought threshold by shifting the threshold to $15 \%$ of the driest dry season months (wide definition) and to $5 \%$ of the driest dry season months (narrow definition). We counted the number of episodicdrought months recorded per year at each site (Fig. 1d) and in a regular $1^{\circ}$ grid across the study area (Fig. S4) to see how the occurrence of episodic droughts has changed over the past decades. Linear regression models were used to investigate correlations between ERA5-derived midday air temperature, midday VPD and number of episodic-drought months per year (Table S3). The subdivision resulted in 2917 monthly observations in the wet season, 2968 in the dry season and 497 during episodic drought. We observe a significantly higher number of episodic-drought months in our meta-analysis than should be expected from the $10 \%$ quantile threshold used for delineating episodic droughts (i.e. 2968). This can be explained by a high number of samples in recent studies that covered the 2015 ENSO drought (e.g. Doughty et al., 2017; Fontes et al., 2018; Maréchaux et al., 2018; Rifai et al., 2018; Santos et al., 2018). 
In addition to monthly observations, stem growth data from the extensive forest inventory dataset of Brienen et al. (2015) were also included in the database. Because these data cover multiple months, we labelled census intervals that included at least 3 months of episodic drought as episodicdrought months and shorter intervals as dry season months for comparison. Finally, monthly values of the multivariate ENSO index for the period 1979-2019 were retrieved from the National Oceanic and Atmospheric Administration (http: //www.esrl.noaa.gov/psd/enso/mei/, last access: 15 November 2019). Strong ENSO years (1996-1997, 2009-2010, 2015-2016) are clearly visible as years with many recorded episodic-drought months (Figs. 1, S4).

\subsection{Meta-analysis}

Quantitative drought responses of different plant physiological and ecosystem-scale processes were synthesized using meta-analytical statistics. The log response ratio was used as a metric of drought effect size and converted back to percentage change for convenient interpretation. The log response ratio is the natural-log proportional difference between the means in a treatment and a control group (Hedges et al., 1999; Lajeunesse, 2011). In this analysis, we compared variables averaged over wet season months to variables averaged over dry season months and, in the second comparison, the variables averaged over the dry season months to variables averaged over the episodic-drought months (Fig. 3). To be clear, we used only natural drought conditions in the metaanalysis and omitted all data that were acquired in artificial drought experiments. Measurements were always available in pairs or as repeated measurements (wet season-dry season, dry season-episodic drought), so the variance of the calculated response ratio has to be adjusted for by the Pearson product correlation coefficient between the measurement pairs (Lajeunesse, 2011). For individual tree measurements, which were available for stomatal conductance, photosynthesis, leaf water potential, tree transpiration and sometimes leaf flushing, the average, standard deviation and correlation coefficient were calculated from the pool of measured trees in each study. When site averages were used, which was the case for all the other variables, the average and standard deviation calculated from the different measurement years were used. The log response ratio and sample variance of the variables in individual studies and sites were calculated using the "escalc" routine and the mean effect sizes and $95 \%$ confidence intervals in the "rma" routine, both available in the $\mathrm{R}$ package "metafor" (Viechtbauer, 2017).

To calculate the average wood density for each study, as a proxy for plant hydraulic behaviour, we created a separate dataset including for each study the genus and species names of the individual trees measured in the study. Preferably, the species-specific wood density was retrieved from the original source. However, if this was not possible, we retrieved wood density from a database of wood properties in Neotropical tree taxa collated previously by us (Janssen et al., 2020) or from the global wood density database (Chave et al., 2009; Zanne et al., 2009). Species-specific wood density was not available in 128 out of 866 measured individuals. For these individuals, the genus-averaged wood density was used instead. In Neotropical tree taxa, $74 \%$ of interspecific variability in wood density can be explained by genus-level variability in wood density (Chave et al., 2006). Therefore we consider genus-averaged wood density as a suitable proxy for species-level wood density in these cases. Furthermore, gap filling using genus-averaged wood density prevents missing values causing a large bias in the study-averaged wood density in studies that measured relatively few species. Studyaveraged wood density was used in the rma routine from the $\mathrm{R}$ package metafor (Viechtbauer, 2017) to test whether wood density was a significant moderator variable in the mixedeffect meta-regression model. This model also used inversevariance weighting of the studies included in the model.

\section{Results}

\subsection{Responses to seasonal drought}

The meta-analysis shows that across the measured Neotropical forest sites, a dry season decline in relative extractable water (REW) is associated with a decline in soil matric potential in the topsoil (Figs. 2a, c, S3). Furthermore, dry season months are characterized by a higher midday air temperature, lower relative humidity and therefore higher vapour pressure deficit (VPD) compared to wet season months (Figs. 1d, 2d). As a result of a decline in water supply from the soil and an increase in evaporative demand from the atmosphere, the meta-analysis indicates that, across studies, predawn and midday $\psi_{1}$ both significantly decline from the wet to the dry season (Figs. 2a, 3a). Predawn $\psi_{1}$ declines from an average of $-0.23 \pm 0.11 \mathrm{MPa}$ in the wet season to $-0.35 \pm 0.28 \mathrm{MPa}$ in the dry season across studies and sites (Fig. 2a). Midday $\psi_{1}$ declines from an average of $-0.89 \pm 0.34$ to $-1.35 \pm 0.41 \mathrm{MPa}$ from the wet to the dry season (Fig. 2a). Therefore, the average midday water potential gradient increases from $0.66 \mathrm{MPa}$ in the wet season to 1.0 MPa in the dry season (Fig. 3b).

The dry season decline in $\psi_{1}$ triggers progressive stomatal closure resulting in a decline in stomatal conductance and leaf photosynthesis of $42 \%$ and $25 \%$, respectively, from the wet to the dry season. As the decline in stomatal conductance outweighs the decline in leaf photosynthesis, intrinsic water use efficiency (iWUE) increases by $27 \%$ from the wet to the dry season (Fig. 3a). These results suggest that, on the leaf scale, increased transpiration in the dry season is largely prevented by progressive stomatal closure, which is also contributing to a decline in leaf photosynthesis.

The meta-analysis shows that, on the tree scale, there is a marginally significant increase in the water potential gra- 

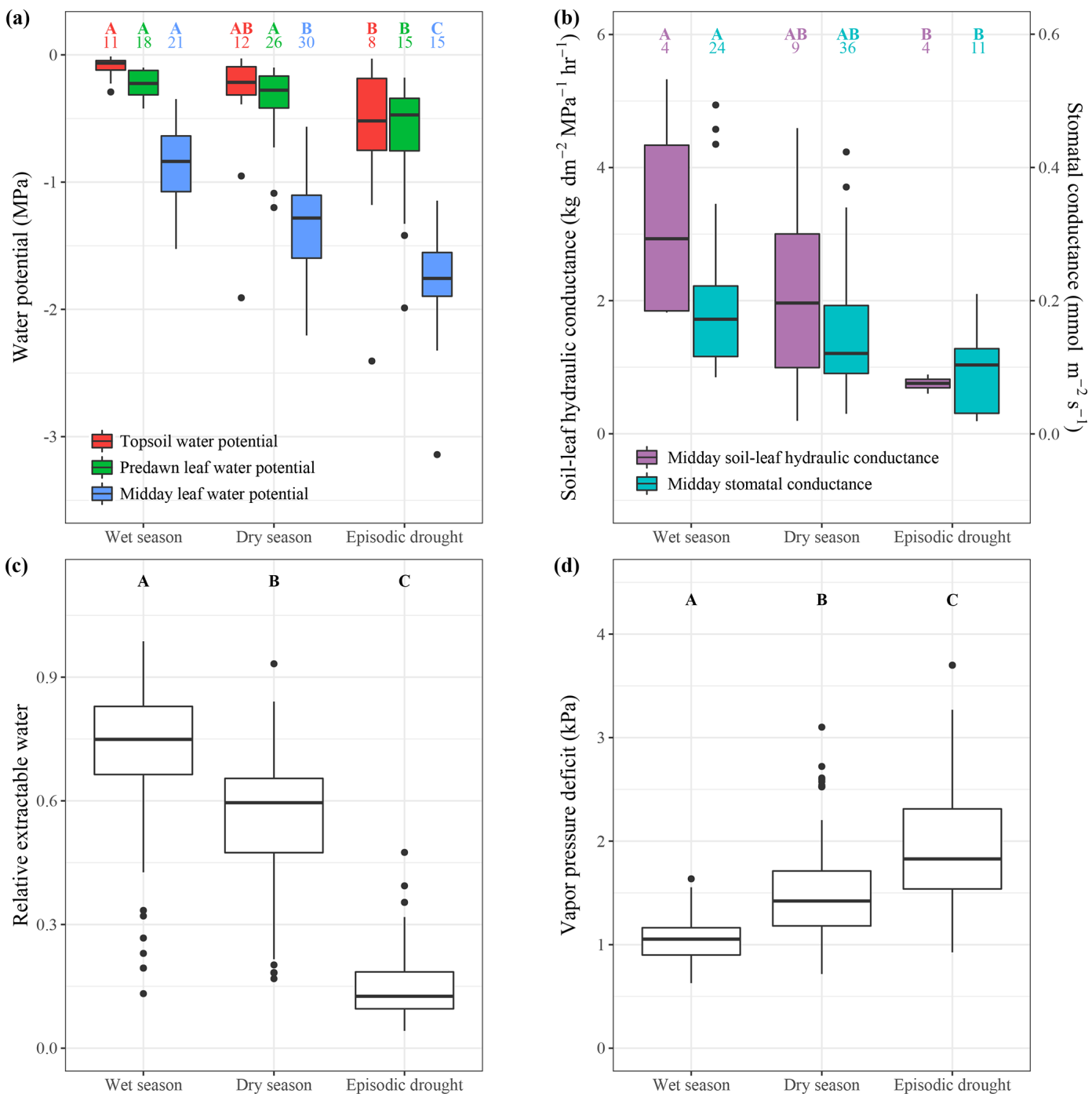

Figure 2. Plant hydraulic status, plant hydraulic conductance, stomatal conductance and environmental drivers in the wet season, dry season and during episodic drought. The boxplots show the median value and interquartile ranges (boxes); the whiskers show the range between minimum and maximum value, and, if present, outliers are indicated as single dots. Soil matric potential, predawn leaf water potential, midday leaf water potential (a), soil-to-leaf hydraulic conductance and stomatal conductance (b) are derived from published data and available in the supplementary database. The numbers above the boxplots in (a) and (b) denote the number of unique source and site combinations at which the variables were averaged. Relative extractable water (c) and vapour pressure deficit (d) are derived from monthly ECMWF ERA5 reanalysis data extracted for 229 Neotropical forest sites in South and Central America (1979-2019). Capital letters indicate a significant ( $p<0.05$, Tukey's honestly significant difference test pairwise difference between the wet season, dry season and episodic-drought values. When a group is not significantly different from the two other groups that are significantly different in the comparison, the capital letters are coupled.

dient, while soil-to-leaf hydraulic conductance is not significantly reduced from the wet to the dry season (Fig. 3b). However, crown conductance is significantly reduced by $25 \%$ from the wet to the dry season, suggesting that the increase in atmospheric VPD is offset by a decline in crown conductance that results in no significant change in daily tree transpiration from the wet to the dry season (Fig. 3b, Eq. 1). The meta-analysis points to a distinct seasonality of alternating stem and canopy growth (Fig. 3b). The shedding of old and flushing of new leaves during the dry season cumulates into an average $30 \%$ higher leaf litterfall and $26 \%$ higher leaf flushing in the dry season compared to the wet season. While canopy growth increases, average stem diameter growth declines by roughly the same magnitude (31\%) from the wet to the dry season (Fig. 3b). These results suggest that, generally, above-ground productivity alternates between stem and canopy growth from the wet to the dry season. 

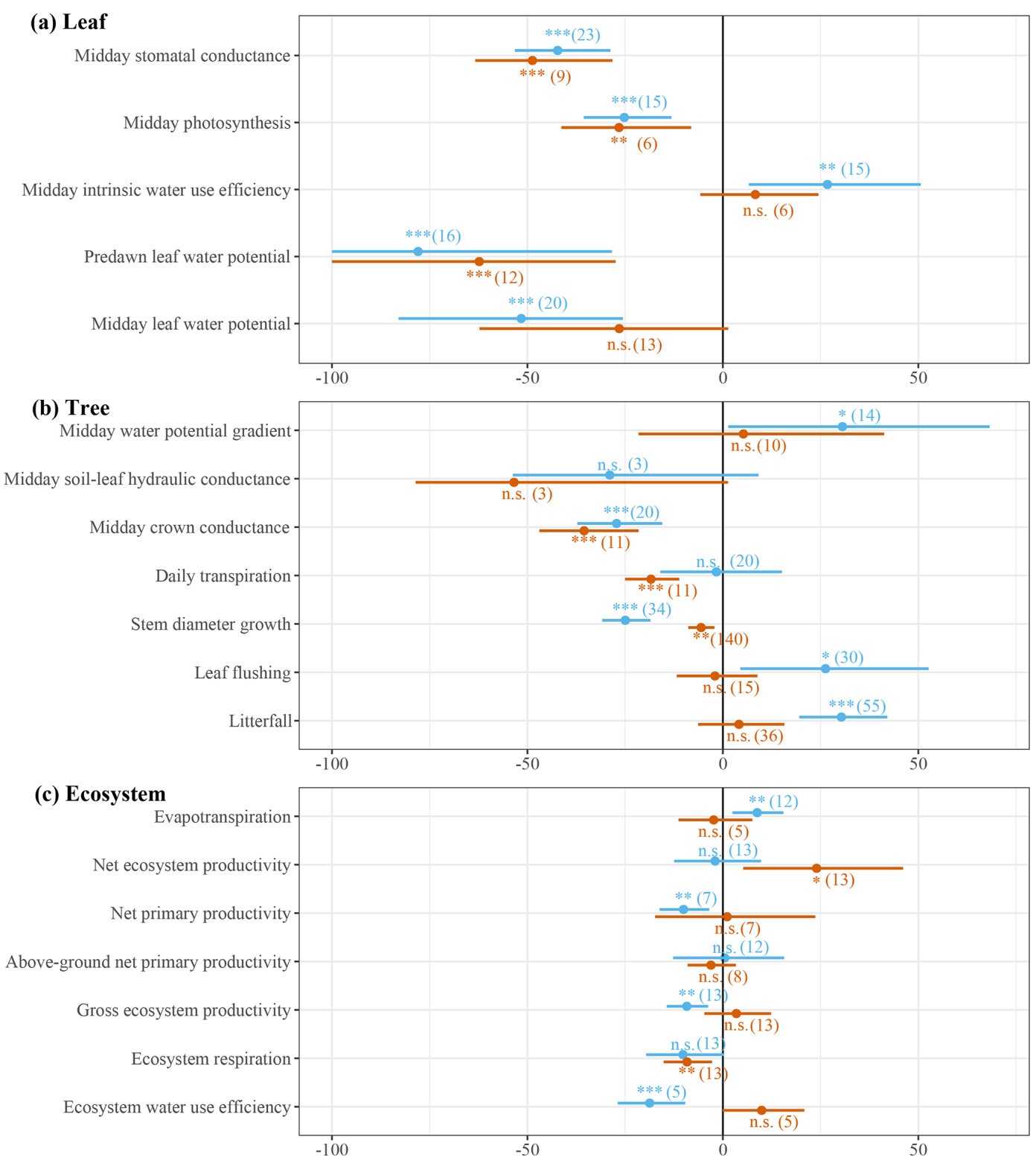

Figure 3. Meta-analysis results of leaf-, tree- and ecosystem-scale responses to seasonal (blue) and episodic (red) drought. The dots are the averages and the horizontal lines represent $95 \%$ confidence intervals of percentage change in leaf-, tree- and ecosystem-scale performance. The confidence intervals for predawn leaf water potential were cut off at $-100 \%$ to prevent the $x$ axis from inflating. Repeated measurements were used; therefore the variance of the response ratio is adjusted for by the correlation coefficient between the repeated measurements (Lajeunesse, 2011). The number of consulted studies or sites is provided in brackets. The significance symbols depict the $p$ value derived from a random-effects model $\left.{ }^{* * *} p<0.001{ }^{* *} p<0.01 ;^{*} p<0.05\right)$ testing whether the effect size differs significantly from 0.

Despite no observed changes in daily tree transpiration, we observed a significant $9 \%$ increase in ecosystem evapotranspiration from the wet to the dry season (Fig. 3c). Furthermore, the meta-analysis also points to a $9 \%$ decline in gross primary productivity (GPP), resulting in a significant $19 \%$ reduction in ecosystem water use efficiency from the wet to the dry season (Fig. 3c). Net primary productivity (NPP) declined by $10 \%$ from the wet to the dry season, but there was no significant change in above-ground net primary produc- tivity (ANPP) from the wet to the dry season (Fig. 3c). This suggests that primarily root growth declines from the wet to the dry season, while increased canopy growth in the dry season is offset by a decline in stem growth (Fig. 4b). Considering the total ecosystem carbon budget, the decline in GPP is offset by a non-significant dry season decline in ecosystem respiration $\left(R_{\mathrm{eco}}\right)$ resulting in no significant change in net ecosystem productivity $\left(\mathrm{NEP}=\mathrm{GPP}-R_{\mathrm{eco}}\right)$ from the wet season to the dry season. 

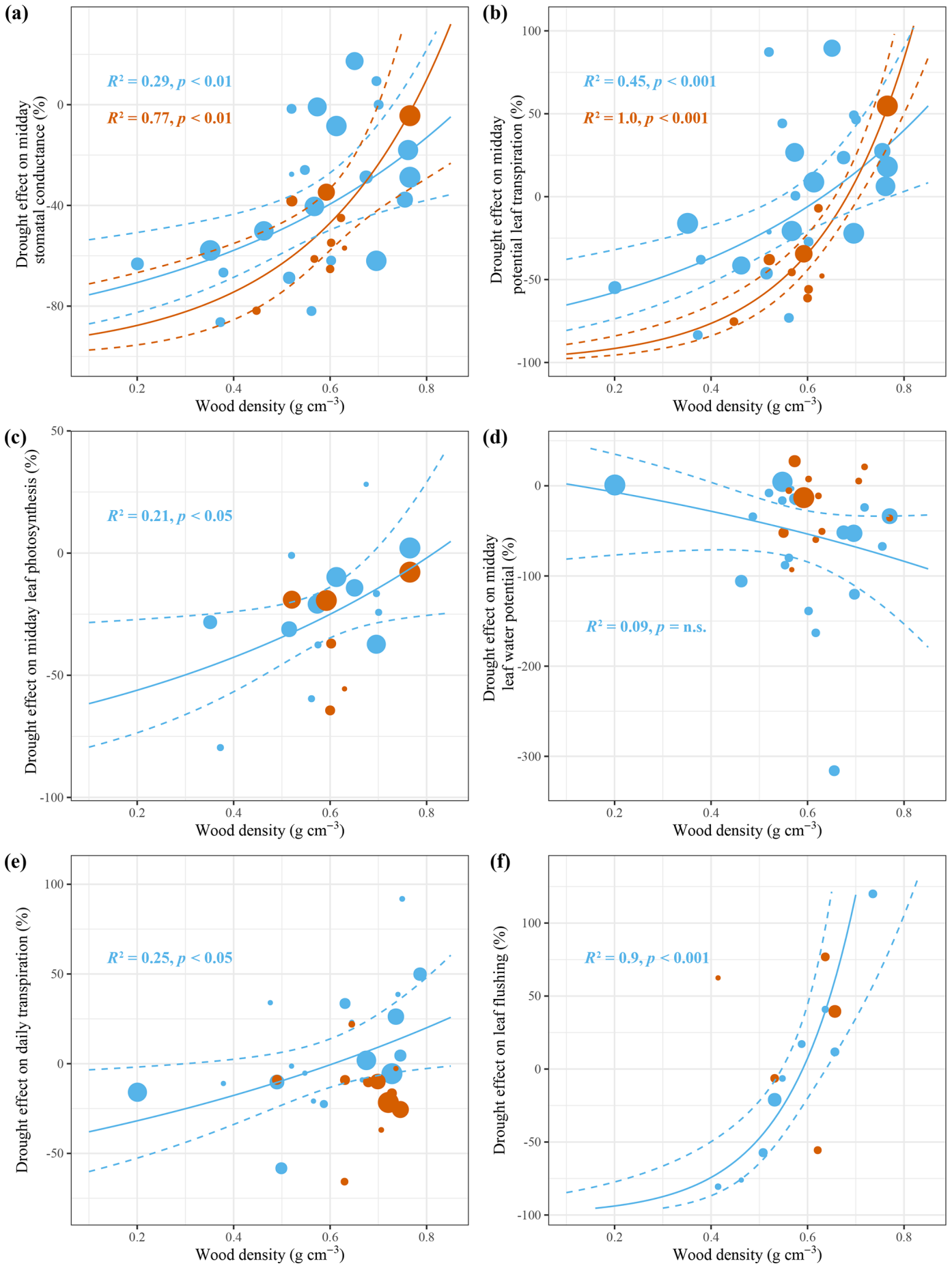

Figure 4. Effect size of leaf- and tree-scale responses to seasonal (blue) and episodic (red) drought for different studies against the studyaveraged wood density. The $R^{2}$ values indicate the amount of heterogeneity accounted for in each mixed-effect model with wood density as a moderator. On the leaf-scale, studies with a low average wood density show a decline in stomatal conductance (a), potential leaf transpiration (b) and photosynthesis (c) in response to seasonal and episodic drought, while midday leaf water potential is not changed. On the tree scale, studies with a low average wood density show a decline in daily tree transpiration (e) and leaf flushing (f) in response to seasonal drought but not episodic drought. The size of the points is determined based on the inverse of the sampling variance of the particular study (i.e. precision), showing larger points for more precise studies. The sampling variances are used to provide weights for the different studies in the mixed-effect model. The test statistics are retrieved from a mixed-effect model testing the significance of wood density as a moderator variable in the drought response. The solid line is the model prediction, and the dashed lines are the $95 \%$ confidence intervals. Regression lines are only drawn if the relationship is significant $(p<0.05)$. 
To test for the sensitivity of the observed responses to our episodic-drought definition, we replicated the meta-analysis using a wide and a narrow drought definition, by setting the drought threshold at either $15 \%$ or $5 \%$, respectively, of the driest dry season months (Sect. 2.3). For seasonal drought, changing the threshold did not significantly change the magnitude or direction of the observed responses (Figs. S8 and S9). Slight changes in the number of studies included in the analysis contributed to the increase in the water potential gradient from the wet to the dry season becoming not significant when using the wide drought definition (Fig. S8b), while the decline in soil-to-leaf hydraulic conductance from the wet to the dry season became marginally significant $(p<0.05)$ when using the narrow drought definition (Fig. S9b). These results suggest that the observed responses to seasonal drought in this meta-analysis are robust, that is, relatively insensitive to changes in the episodic-drought threshold.

\subsection{Responses to episodic drought}

We found that, on average, the number of months per year classified as episodic drought has been increasing since 1979, both in the studied plots (Fig. 1b) and across the entire study area (Fig. S4). The number of episodic-drought months per year increased significantly over time $(r=0.62, p<0.001)$ and was positively correlated to annual averaged midday air temperature $(r=0.82, p<0.001)$ and vapour pressure deficit $(r=0.88, p<0.001)$, indicating both drying and warming over the past 4 decades (Fig. S4, Table S3). Several previously described drought events related to El Niño in 1983, 1987, 1997, 2010 and 2015 are superimposed on this trend and clearly visible as years with high midday air temperatures and VPD and relatively many episodic-drought months per year (Figs. 1b, d, e, S4).

Episodic droughts are associated with a higher VPD and a lower $\psi_{\mathrm{s}}$ compared to a regular dry season (Figs. 1d, 2a, d). Consequently, the predawn $\psi_{1}$ is on average $0.32 \mathrm{MPa}$ lower $(-0.67 \pm 0.52 \mathrm{MPa})$ during episodic drought compared to during an average dry season $(-0.35 \pm 0.28 \mathrm{MPa}$; Figs. 2a, $3 \mathrm{a})$. Midday $\psi_{1}$ declines from $-1.35 \pm 0.41 \mathrm{MPa}$ in the dry season to $-1.8 \pm 0.48 \mathrm{MPa}$ during episodic drought, increasing the average water potential gradient by $0.13 \mathrm{MPa}$ across all measured trees. However, the meta-analysis indicates that this increase is not significant across studies, as there is a large variability in the water potential gradient response to episodic drought (Fig. 3b). The decline in midday $\psi_{1}$ in response to episodic drought is related to a $49 \%$ reduction in stomatal conductance and $27 \%$ reduction in leaf photosynthesis compared to in a regular dry season (Fig. 3a). Similar to that observed in response to seasonal drought, we observe a small increase in iWUE in response to episodic drought, but this response is not significant (Fig. 3a).

On the tree scale, there is no significant change in the water potential gradient during episodic drought compared to during a regular dry season, and also the substantial average decline of $53 \%$ in soil-to-leaf hydraulic conductance during episodic drought compared to a regular dry season is not significant (Fig. 3b). Nonetheless, we do observe a significant decline of $36 \%$ in crown conductance and an $18 \%$ decline in daily tree transpiration in response to episodic drought (Fig. 3b). Furthermore, stem diameter growth is reduced by an average of $6 \%$ during episodic drought compared to during a regular dry season, while leaf flushing and litterfall are not significantly different (Fig. 3b).

On the ecosystem scale, despite the decline in tree transpiration, the meta-analysis suggests that evapotranspiration during episodic drought is not significantly different to the evapotranspiration in the dry season (random-effects model, $p=0.63, n=5$ ). Furthermore, despite declines in stem growth and leaf photosynthesis during episodic drought (Fig. 3a, b), there are no significant differences in GPP, NPP, ANPP and ecosystem water use efficiency during episodic drought compared to during a regular dry season (Fig. 3c). However, we do observe a significant $9 \%$ decline in ecosystem respiration that is driving a $24 \%$ increase in net ecosystem productivity in response to episodic drought (Fig. 3c). These results suggest that ecosystem productivity is relatively tolerant to episodic drought, while reduced respiration contributes to a net increase in ecosystem carbon uptake during episodic drought compared to during a regular dry season.

The sensitivity analysis showed that some episodicdrought responses are sensitive to changes in the episodicdrought threshold, especially on the leaf scale (Figs. S8, S9). When using both the narrow and wide episodic-drought definition, the decline in leaf photosynthesis in response to episodic drought became not significantly different from a regular dry season anymore (Figs. S8a, S9a). For the narrow definition this is mainly the result of using only half the number of studies compared to the baseline analysis, reducing the statistical power of the test. In the wide definition analysis, the effect size, or the difference between the episodicdrought and a regular dry season month, becomes smaller. Choosing an arbitrary episodic-drought threshold to compare a regular dry season with an episodic drought will always result in uncertainties in the observed responses. However, after testing the sensitivity of the episodic-drought threshold, we conclude that most of the observed responses to seasonal and episodic drought are robust while highlighting the importance of choosing an episodic-drought threshold that is strict enough (i.e. only includes exceptionally dry conditions) but still yields a large enough sample size for the statistical analysis to differentiate data.

\subsection{Relationships between study-averaged wood density and drought responses}

The meta-analysis revealed that, on average, stomatal conductance and leaf photosynthesis are downregulated as predawn and midday $\psi_{1}$ decline during seasonal and episodic 
drought. Furthermore, we find that between-study variation in the stomatal conductance, potential leaf transpiration and leaf photosynthesis response to seasonal and episodic drought correlates with differences in study-averaged wood density. Generally, studies that measured mainly low-wooddensity tree species showed a stronger response of stomatal conductance and potential leaf transpiration to seasonal and episodic drought compared to studies that measured mainly high-wood-density species (Fig. 4a, b). Interestingly, wood density explains more variation in the response of potential leaf transpiration than in the response of stomatal conductance to seasonal and episodic drought, while potential leaf transpiration is derived from stomatal conductance (Eq. 8). This can be explained by differences in atmospheric VPD between different studies and indicates that the relationship between study-averaged wood density and the drought-induced decline in stomatal conductance is largely driven by a drought-induced increase in atmospheric VPD (Fig. 2). Therefore, drought-avoiding lowwood-density species downregulate potential leaf transpiration in response to drought through stomata closure and not stomatal conductance per se.

Also the magnitude of a decline in leaf photosynthesis in response to seasonal drought decreased with increasing wood density (Fig. 4c). However, this relationship was not visible in response to episodic drought (Fig. 4c). There was also no significant effect of wood density on the response of midday $\psi_{1}$ to seasonal or episodic drought (Fig. 4d), but there was a significant relationship between the episodicdrought response of predawn $\psi_{1}$ and study-averaged wood density ( $R^{2}=0.76, p<0.05$, not shown). Generally, studies that measured high-wood-density species showed a stronger decline in predawn $\psi_{1}$ in response to episodic drought compared to studies that measured low-wood-density species. These results suggest that low-wood-density species are better able to maintain a high predawn $\psi_{1}$ during episodic drought, possibly because of strong stomatal control on transpiration (Fig. 4a, b), higher sapwood capacitance or deepsoil-water accessibility that enables recharging of tissue water at night.

For similar reasons, we find that the response of midday $\psi_{1}$ to a decline in predawn $\psi_{1}$ is also strongly dependent on study-averaged wood density (Fig. S5). Tree species from studies with a high average wood density $\left(>0.7 \mathrm{~g} \mathrm{~cm}^{-3}\right)$ showed a strong reduction in midday $\psi_{1}$ and an increase in the water potential gradient in response to a decline in predawn $\psi_{1}$. On the other hand, tree species in studies with a low-average-wood-density species $\left(<0.5 \mathrm{~g} \mathrm{~cm}^{-3}\right)$ show a non-significant decline in midday $\psi_{1}$ in response to a decline in predawn $\psi_{1}$. Studies with intermediate average wood density $\left(0.5-0.7 \mathrm{~g} \mathrm{~cm}^{-3}\right)$ show a decline in midday $\psi_{1}$ parallel to a decline in predawn $\psi_{1}$ (slope $\sim 1$; Fig. S2). Related to these results we found that the stomatal response to atmospheric VPD also depends on study-averaged wood density, with low-wood-density species showing strong stomatal downreg- ulation in response to increased atmospheric VPD, while no stomatal downregulation is observed in high-wood-density species (Fig. S6). These results imply that low-wood-density species prevent a midday drop in $\psi_{1}$ during seasonal and episodic drought by downregulating stomatal conductance, potential leaf transpiration and photosynthesis in response to elevated midday VPD, while high-wood-density tree species keep a more variable $\psi_{1}$ and have no strong stomatal control on potential leaf transpiration.

The dry season responses of the two tree-scale variables for which enough species-specific data were available, daily tree transpiration and leaf flushing, also showed significant relationships with study-averaged wood density (Fig. 4e, f). The relationship between study-averaged wood density and the magnitude of the seasonal drought response of daily tree transpiration was similar in terms of magnitude and direction to the relationship between wood density and the potential leaf transpiration response (Fig. 4b, e). Roughly half of the studies that measured mainly low-wood-density species showed a dry season decline in daily tree transpiration. The other half of the studies that measured mainly highwood-density species showed a dry season increase in daily tree transpiration (Fig. 4e). Similarly, dry season leaf flushing is found to be more pronounced in high-wood-density species compared to in low-wood-density species that actually show on average a decline in leaf flushing in the dry season (Fig. 4f). Finally we find that study-averaged stomatal conductance, leaf photosynthesis, midday $\psi_{1}$, daily tree transpiration, soil-to-leaf hydraulic conductance and crown conductance all significantly decline with increasing studyaveraged wood density (Fig. S7). These results suggest that low-wood-density species, compared to high-wood-density species, not only are characterized by efficient water transport, high stomatal conductance and leaf photosynthesis during the wet season but also show a strong decline in stomatal conductance, transpiration and photosynthesis in response to drought.

\section{Discussion}

\subsection{How do leaf-, tree- and ecosystem-scale processes respond to seasonal drought?}

Stomatal behaviour, changes in soil-to-leaf hydraulic conductance and differences in hydraulic architecture determine the hydraulic response to seasonal drought in Neotropical trees, driving tree transpiration and ecosystem evapotranspiration (Figs. 2, 3). The downregulation of stomatal conductance and canopy conductance in the dry season is a widely observed hydraulic response to a decline in leaf and xylem water potential (Fisher et al., 2006; Machado and Tyree, 1994; Williams et al., 1998). However, progressive stomatal closure and the decline in hydraulic conductance and crown conductance are offset by a higher midday VPD and an in- 
crease in the water potential gradient (midday $\psi_{1}$-predawn $\psi_{1}$ ) in the dry season, resulting in no observed change in daily tree transpiration from the wet to the dry season across studies (Fig. 3). The decline in soil-to-leaf hydraulic conductance in the dry season is the result of embolism formation in the xylem vessels that reduces xylem hydraulic conductance (Bonal et al., 2000a; Fontes et al., 2018; Machado and Tyree, 1994; Meinzer et al., 2008b). Our data did not allow us to disentangle whether dry season transpiration is mainly constrained by a decline in stomatal conductance or a decline in soil-to-leaf hydraulic conductance. However, the declines in hydraulic conductance and stomatal conductance with decreasing xylem water potential are strikingly similar, (Brodribb et al., 2003) suggesting that xylem hydraulic vulnerability and stomatal sensitivity are strongly coordinated (Fontes et al., 2018; Maréchaux et al., 2018; Meinzer et al., 2008b).

The meta-analysis suggests that the dry season downregulation of stomatal conductance is accompanied by a smaller but significant decline in leaf photosynthesis (Fig. 3a). Therefore, the leaf-scale intrinsic water use efficiency (iWUE) increases on average from the wet to the dry season (Fig. 3a). This increase in iWUE in the dry season was also found in earlier site-specific studies (Bonal et al., 2000a; Hogan et al., 1995; Santos et al., 2018). However, as gross primary productivity (GPP) declines and evapotranspiration increases, we observe a decline in ecosystem water use efficiency from the wet to the dry season (Fig. 3c). Therefore, our results suggests that, despite leaf-level iWUE increases from the wet to the dry season, Neotropical forests actually become less water efficient in the dry season. This is in agreement with a global synthesis of eddy-covariance measurements that showed that humid tropical forests show a decline in ecosystem water use efficiency in response to drought (Yang et al., 2018a).

The meta-analysis results show that across Neotropical forests, net primary productivity (NPP) declines while above-ground NPP (ANPP) does not change from the wet to the dry season (Fig. 3c). This suggests that the decline in total NPP is primarily the result of a decline in root growth in the dry season. We confirm earlier findings that root growth declines with a decline in soil moisture in the dry season (Girardin et al., 2016; Metcalfe et al., 2008). Furthermore, we find that above-ground growth is shifted from the stem in the wet season to the canopy in the dry season (Fig. 3b) without changes in overall above-ground growth. Finally, the metaanalysis shows that the dry season decline in GPP is offset by the decline in ecosystem respiration, resulting in no significant change in net ecosystem productivity from the wet to the dry season (Fig. 3c). The dry season decline in ecosystem respiration is likely driven by a decline in heterotrophic respiration from the soil and litter layer as soil and litter respiration is found to be strongly dependent on the availability of moisture in Neotropical forests (Chambers et al., 2004; Sotta et al., 2004; Zanchi et al., 2014).

\subsection{How do leaf-, tree- and ecosystem-scale processes respond to episodic drought?}

Episodic droughts seem to have become more common in South and Central America recently. Previously classified as occurring once in a century, episodic droughts are now occurring roughly every 5 years (Aragão et al., 2007; Coelho et al., 2012; Erfanian et al., 2017; Marengo et al., 2008, 2011; Panisset et al., 2017). Furthermore, ENSO extremes that are clearly linked to major droughts in Neotropical forests (Figs. 1, S4) have been intensifying in the 20th and 21st century (Grothe et al., 2019). Following our definition of episodic drought, we observe a significant increase in the number of episodic-drought months per year since 1979, both across the 232 Neotropical forest sites (Fig. 1b) and across the entire Neotropical forest biome (Fig. S4). Although this drying trend might be the result of an underlying bias in the ERA5 reanalysis product, the result is in agreement with the analysis of alternative datasets indicating that dry seasons in Amazonia have been becoming dryer since 1979 (Fu et al., 2013). The mechanisms driving this dry season drying are uncertain but have been attributed to changes in global atmospheric circulation (Fu et al., 2013) and more regionally to deforestation (Costa and Pires, 2010; Debortoli et al., 2017). We also find that midday air temperature and VPD have been increasing over the same period (Fig. S4), suggesting that episodic drought has become not only more frequent but also hotter since 1979. In this meta-analysis, we were able to use leaf-, tree- and ecosystem-scale data from 5 major episodic-drought years, namely from 1987, 1997, 2005, 2010 and 2015 (Fig. 1).

Episodic droughts reduce the supply of water from the soil and increase the evaporative demand of the atmosphere beyond values that are observed in a regular dry season (Fig. 2; see also Jiménez-Muñoz et al., 2016; Lee et al., 2013; Panisset et al., 2017). We find that both stomatal conductance and photosynthesis are reduced during episodic drought compared to during a regular dry season (Fig. 3a). This suggests that the physiological responses to episodic drought on the leaf level are, in terms of direction and magnitude, a continuation of the seasonal drought response. Stomatal limitations may explain the observed decline in leaf photosynthesis in response to episodic drought, as changes in nutrient or chlorophyll concentrations were not reported for the 2015 drought in the central Amazon (Santos et al., 2018). Alternatively, reductions in carboxylation capacity and mesophyll conductance in response to leaf desiccation or high leaf temperatures could cause a more permanent reduction in photosynthesis during episodic drought (Dewar et al., 2018; Doughty, 2011; Felsemburgh, 2009; Lloyd and Farquhar, 2008; Zhou et al., 2013). The average midday $\psi_{1}$ observed during episodic drought $(-1.8 \mathrm{MPa})$ induces leaf turgor loss in many tropical rainforest trees (Maréchaux et al., 2015). The importance of tissue desiccation and heat-induced damage to the photosynthetic machinery is presently not known 
but could become increasingly important in the tropical carbon cycle in a warmer climate.

The meta-analysis results suggest that stem growth is significantly reduced during episodic drought, while leaf litterfall and leaf flushing do not show a consistent positive or negative change (Fig. 3b). The decline in stem growth during episodic drought is widely observed across tropical humid forests and has been linked to a temporary decline in tropical forest carbon sink (Brienen et al., 2015; Clark et al., 2003, 2018; Feldpausch et al., 2016; Rifai et al., 2018). However, declines in stem growth are not always obvious (Doughty et al., 2014, 2015; Phillips et al., 2009) and are at some sites compensated for by an increase in canopy growth or root growth (Doughty et al., 2015; Hofhansl et al., 2014), resulting in no observed net change in NPP or ANPP during episodic drought (Fig. 3c). These results suggest that, despite significant reductions in leaf photosynthesis during episodic drought, overall tree growth is not limited by carbohydrate availability (carbon starvation; Mcdowell et al., 2008; Sala et al., 2012). Evidence from Neotropical humid forests suggests that leaf and wood tissue concentrations of non-structural carbohydrates (NSCs) are kept relatively constant during seasonal and severe episodic drought (Dickman et al., 2019; Würth et al., 2005). This implies that temporary reductions in photosynthesis are not sufficient to limit actual tree growth during drought (Würth et al., 2005). The significant decline in stem growth in response to episodic drought is more likely driven by cell turgor loss in the vascular cambium as a result of tissue desiccation, which limits cell formation and thus the formation of new tissue in the stem (Körner and Basel, 2013; Krepkowski et al., 2011; Muller et al., 2011). It is essential to understand which mechanisms, turgor mediated, carbon mediated or a combination of both, are driving drought-induced declines in tree growth, as they can operate on different timescales and can have different sensitivities to drought.

\subsection{What are the differences between seasonal and episodic drought?}

We find that the responses of stomatal conductance, leaf photosynthesis and midday and predawn $\psi_{1}$ to episodic drought are basically a continuation of the same leaf physiological responses observed during seasonal drought (Figs. 2, 3). However, unlike seasonal drought, the decline in crown conductance outweighs the increase in atmospheric VPD during episodic drought, effectively reducing daily tree transpiration (Fig. 4a, b, Eq. 1). Our results are in agreement with site-specific observations that daily tree transpiration is reduced through a combination of stomatal downregulation and a loss of soil-to-leaf hydraulic conductance, both in response to episodic drought (Fontes et al., 2018) and multiyear drought (Fisher et al., 2006). Unlike the rapid recovery of stomatal conductance, soil-to-leaf hydraulic conductance has been observed not to recover fully after episodic drought
(Fontes et al., 2018), imposing a legacy effect on transpiration in the first months following episodic drought. Furthermore, the loss of hydraulic conductance might be considered an early warning signal for embolism-induced drought mortality (Rowland et al., 2015b) following episodic drought (Feldpausch et al., 2016; Phillips et al., 2009). The decline in tree transpiration in response to episodic drought likely results in the decline in the surface latent heat flux and increase in the surface sensible heat flux, causing a further drying and warming of the atmosphere (Harper et al., 2014).

Contrary to seasonal drought, we observe no increase in leaf flushing and litterfall and no significant declines in NPP and GPP during episodic drought. One explanation for this apparent discrepancy is that leaf flushing, litterfall, NPP and GPP operate on seasonal timescales and are strongly dependent on tree phenology. Most Neotropical tree species shed old and flush new leaves during the dry season as their leaf phenology is synchronized with maximum daily insolation (Borchert et al., 2015; Bradley et al., 2011; Brando et al., 2010; Graham et al., 2003; Wagner et al., 2016; Wright and van Schaik, 1994). This results in an initial decline followed by a progressive increase in photosynthetic capacity on the ecosystem scale in the late dry season as leaves mature (Albert et al., 2018; Doughty and Goulden, 2009b; Wu et al., 2016). Leaf flush and maturation, and with it the increase in leaf photosynthetic capacity, drive a progressive increase in GPP during the dry season in humid Neotropical forests (Albert et al., 2018; Araújo et al., 2016; Doughty and Goulden, 2009b; Hutyra et al., 2007; Restrepo-Coupe et al., 2013). Episodic droughts by our definition always occur at the end of the dry season, when REW is lowest (Fig. 1). Therefore, the peaks in litterfall and leaf flush that generally occur in the first half of the dry season have already occurred before the episodic drought starts, and therefore GPP is relatively high. We hypothesize that the seasonal timescales of tree phenology and ecosystem productivity could be counteracting the potential negative effects of short episodic droughts on GPP, which were therefore not observed in the meta-analysis.

\subsection{How do we scale from the leaf to the ecosystem?}

Our meta-analysis indicates a general tendency of seasonal and episodic-drought responses to become smaller and not significant when going from the leaf and tree scale to the ecosystem scale. Regarding transpiration, we observed sustained daily tree transpiration in the dry season and a decline of daily tree transpiration in response to episodic drought (Fig. 3b). In contrast, ecosystem evapotranspiration increases significantly in the dry season and does not significantly change during episodic drought (Fig. 3c). This discrepancy is not logically explained by an increased contribution of evaporation from the soil and canopy to evapotranspiration, as both soil and canopy evaporation are expected to be lower in the dry season and during episodic drought compared to during the wet season (Shuttleworth, 1988). A more likely 
explanation is that the leaf- and tree-scale data used in our meta-analysis are biased towards fast-growing pioneer tree species with low wood density that are growing in upper canopy positions (e.g. Dünisch and Morais, 2002; Huc et al., 1994; Kunert et al., 2010; Machado and Tyree, 1994).

Stomatal control on transpiration is stronger in low-wooddensity compared to high-wood-density tree species (Figs. 4, S6). Furthermore, sun-exposed trees in upper canopy positions experience a higher evaporative demand from the atmosphere, resulting in a more pronounced downregulation of stomatal conductance and photosynthesis in response to seasonal and episodic drought, compared to that experienced by understorey trees (Domingues et al., 2014; Fisher et al., 2006; Santos et al., 2018). This sample bias in the metaanalysis might also explain why ecosystem-scale responses of carbon exchange to drought seem to contradict the observations on the leaf and tree scale. The decline in leaf photosynthesis is more than twice the magnitude of the decline in GPP during seasonal drought, while in response to episodic drought there is not even a decline in GPP detected (Fig. 3). This meta-analysis result is confirmed by unexpected results from previous studies that found that GPP and NPP are not reduced during episodic drought despite significant declines in leaf photosynthesis (Bonal et al., 2008; Doughty et al., 2014, 2015).

Another explanation for the apparent contradiction between leaf-, tree- and ecosystem-scale responses to episodic drought is the limited timescale on which we analysed ecosystem drought responses. The temporal scale of some tree- and ecosystem-scale responses to episodic drought might extend far beyond the actual drought (e.g. Gonçalves et al., 2020; Hofhansl et al., 2014). For example, episodicdrought events have been found to elevate tree mortality rates across Neotropical forests (Condit et al., 1995; Feldpausch et al., 2016; Phillips et al., 2009; Williamson et al., 2000). Tree mortality can significantly impact ecosystem productivity and transpiration, carbon storage, and canopy structure, impacting the understorey light environment and microclimate for many years (da Costa et al., 2018; Leitold et al., 2018; Rice et al., 2004; Rowland et al., 2018; Saatchi et al., 2013; Yang et al., 2018a). Furthermore, extensive leaf flushing in the first months after an episodic drought have been reported (Doughty et al., 2014, 2015; Gonçalves et al., 2020; Hofhansl et al., 2014), contributing to ANPP exceeding pre-drought values in the years directly following episodic drought (Doughty et al., 2014, 2015; Hofhansl et al., 2014). These legacy effects of drought are not captured by our meta-analysis, which is a limitation of the method used. Therefore, we were unable to grasp the complete or final extent of the tree- and ecosystem-scale responses to episodic drought.

\subsection{How is wood density related to leaf- and tree-scale responses to drought?}

The meta-analysis shows that the magnitude and direction of the stomatal conductance, leaf photosynthesis, potential leaf transpiration, daily tree transpiration and leaf flushing response to seasonal drought are strongly related to the wood density of trees measured in a particular study (Fig. 4). The same relationship was observed for stomatal conductance and potential leaf transpiration in response to episodic drought (Fig. 4). Generally, we find that studies that measured tree species with a relatively low wood density showed a drought-avoiding response, including strong stomatal control on transpiration and no dry season leaf flushing (Fig. 4). Conversely, studies that measured tree species with a relatively high wood density showed no stomatal downregulation, increased leaf- and tree-scale transpiration, and increased leaf flushing in the dry season (Fig. 4). As a result, high-wood-density trees show a stronger desiccation of the leaves and stem during drought and a lower midday leaf and xylem water potential (Figs. S5, S7; Borchert, 1994; De Guzman et al., 2017; Meinzer et al., 2008b; Sterck et al., 2014). Wood density appears to be a good proxy for hydraulic behaviour and could well be used to predict responses of stomatal conductance, transpiration and leaf flushing to seasonal and episodic drought (see e.g. Christoffersen et al., 2016).

Differences in wood density among tree species have been widely studied and are linked to differences in plant hydraulic architecture and hydraulic properties such as hydraulic conductance, sapwood capacitance and embolism resistance (Baas et al., 2004; Chave et al., 2010; Janssen et al., 2020; Poorter et al., 2010). The use of wood density as a proxy for more fundamental hydraulic properties has been criticized as it often lacks a functional basis (Lachenbruch and Mcculloh, 2014; Patiño et al., 2012). Sapwood capacitance, the amount of water released from the xylem under a certain pressure, is arguably the only hydraulic property that is functionally related to wood density, as the amount of space available for water storage in the wood scales inversely with wood density (Janssen et al., 2020; Meinzer et al., 2008b; Poorter, 2008; Pratt and Jacobsen, 2017; Ziemińska et al., 2019). Sapwood capacitance is positively related to maximum stomatal conductance, leaf photosynthesis, daily tree transpiration, soil-to-leaf hydraulic conductance and midday $\psi_{1}$ (Meinzer et al., 2003; Oliva Carrasco et al., 2015; Santiago et al., 2004). We show that these relationships hold when relating not species but study-averaged wood density, as a proxy for sapwood capacitance, to study-averaged stomatal conductance, leaf photosynthesis, daily tree transpiration, midday $\psi_{1}$, crown conductance and soil-to-leaf hydraulic conductance (Fig. S7). Our results suggest that wood density, via sapwood capacitance, is largely driving the magnitude of the stomatal and transpiration response to seasonal and episodic drought in Neotropical trees. 
The difference in hydraulic behaviour between low-wooddensity and high-wood-density tree species is confirmed by the observation that the decline in stomatal conductance with atmospheric VPD and the slope of the relationship between midday $\psi_{1}$ and predawn $\psi_{1}$ are strongly dependent on wood density (Figs. S5, S6). We find that low-wooddensity trees with high sapwood capacitance show a relatively high maximum soil-to-leaf hydraulic conductance as stored water is used for transpiration (Fig. S7), while stomatal conductance is downregulated with increasing VPD in the dry season to avoid dehydration (Fig. S6; Goldstein et al., 1998; Meinzer et al., 2004, 2008b). Conversely, in high-wood-density trees, transpiration is primarily constrained by the relatively low soil-to-leaf hydraulic conductance all year round and stomatal downregulation plays a minor role. High-wood-density trees maintain stomatal conductance $\left(0.07-0.14 \mathrm{~mol} \mathrm{~m}^{-2} \mathrm{~s}^{-1}\right)$ even during severe episodic drought (Alexandre, 1991; Bonal et al., 2000a; Roberts et al., 1990; Santos et al., 2018; Stahl et al., 2013b). This implies that transpiration has to increase during seasonal and episodic drought in high-wood-density trees, resulting in a significant decline in midday $\psi_{1}$ (Figs. 4, S5; Alexandre, 1991; Bonal et al., 2000a; Brum et al., 2019; Domingues et al., 2014). The observed insensitivity of stomatal conductance to VPD in high-wood-density trees has been reported previously for lowland rainforest species (Bonal et al., 2000a; Domingues et al., 2014; Granier et al., 1992; Huc et al., 1994). Stomatal insensitivity to VPD is a possible adaptation to surviving in a humid and deeply shaded understorey, as the $\mathrm{CO}_{2}$ concentration inside the leaf is kept high to maximize photosynthesis during brief moments of high irradiance, known as sun flecks (Domingues et al., 2014; Pons et al., 2005; Tinoco-Ojanguren and Pearcy, 1992).

The capability to maintain stomatal conductance and transpiration during short episodic droughts has been explained by the uptake of deep soil moisture using tap roots (Bonal et al., 2000a; Brum et al., 2019; Meinzer et al., 1999; Nepstad et al., 1994; Stahl et al., 2013a, b). Soil water at a depth of up to $18 \mathrm{~m}$ was found to be accessible for trees at Tapajós in the eastern Amazon (Davidson et al., 2011), enabling trees to maintain a favourable water status during short dry periods. This also becomes clear from the relatively high average predawn $\psi_{1}$ during episodic drought $(-0.67 \mathrm{MPa})$, compared to that of tree species of tropical dry forest where predawn $\psi_{1}$ can approach $-2.5 \mathrm{MPa}$ in a regular dry season, inducing leaf wilting and high mortality rates in tree seedlings (Sobrado, 1986; Veenendaal et al., 1996). Soil depth, root functioning and differences in root architecture are believed to be crucial regulators during drought (Brum et al., 2019; Meinzer et al., 1999; Stahl et al., 2013a), but a lack of data in Neotropical forests prevented us from including these traits in our metaanalysis.

Deep-soil-moisture uptake is not always sufficient to maintain a favourable water status within the tree as droughtinduced tree mortality events have been widely observed across the neotropics (Condit et al., 1995; Feldpausch et al., 2016; Phillips et al., 2009; Williamson et al., 2000), likely resulting from hydraulic failure (Rowland et al., 2015b). The effect of an increased evaporative demand during drought should not be overlooked, as a high VPD can trigger xylem embolism in trees even when soil water is still easily accessed (Fontes et al., 2018; Phillips et al., 2001). Our results point to the lack of drought avoidance in high-wooddensity tree species as stomatal conductance and transpiration are sustained under high evaporative demand, resulting in a strong decline in xylem and leaf water potential during drought (Figs. 4, S5, S6). However, many high-wood-density tree species in humid Neotropical forests have evolved in permanently wet environments and are not necessarily tolerant to xylem embolism (Janssen et al., 2020; Powell et al., 2017; Santiago et al., 2018). The combination of relatively low sapwood capacitance, limited stomatal control on transpiration and limited embolism resistance can amount to high droughtinduced mortality rates in some of these high-wood-density tree taxa (Janssen et al., 2020). This highlights the fact that a lack of properties contributing to drought avoidance in a particular individual or species is not always compensated for by a high drought tolerance, making this individual or species highly vulnerable to drought-induced mortality.

\section{Conclusions}

In this study, we performed a meta-analysis that provides a quantitative overview of leaf, tree and ecosystem responses to seasonal and episodic drought in Neotropical humid forest. We find that the observed leaf-scale responses to episodic drought are a continuation of the responses observed during seasonal drought: reductions in leaf water potential, stomatal conductance and photosynthesis. The observed dry season decline in stem growth and increases in leaf flushing and litterfall seem to be unrelated to water stress. Rather, the seasonal oscillation of growth allocation between stem and canopy seems to be driven by tree phenology which is synchronized with maximum incoming solar radiation in the dry season. Drought responses related to stomatal and hydraulic conductance, transpiration, and photosynthesis are adequately captured by our approach because these responses occur on relatively short timescales of hours and weeks with the opening and closure of leaf stomates, the occurrence of xylem embolism, and the flushing of new leaves. However, tree- and ecosystem-scale responses related to productivity and growth allocation are also dependent on carbohydrate status which operates on seasonal to multi-annual timescales. The meta-analysis confirms that the variability in and magnitude of drought responses decline when going from the individual leaf to the ecosystem level in highly diverse tropical forests. Biodiversity-driven dynamics at the community level, such as niche partitioning, likely contribute to ecosystem resistance and resilience in response to episodic 
drought. Finally, we found that wood density, via its direct relationship with sapwood capacitance, acts as a good proxy for hydraulic behaviour and largely explains the magnitude of stomatal and transpiration responses to seasonal and episodic drought.

Data availability. The data compiled for this study and used in the meta-analysis are available at https://hdl.handle.net/10411/ 41KALW (Janssen, 2020).

Supplement. The supplement related to this article is available online at: https://doi.org/10.5194/bg-17-2621-2020-supplement.

Author contributions. TJ, SL and HD designed the research; TJ, $\mathrm{KF}, \mathrm{SL}, \mathrm{KN}$ and HD coordinated the writing and contributed ideas; TJ compiled the database and analysed the data; KF, SL, KN and HD assisted with writing the final manuscript.

Competing interests. The authors declare that they have no conflict of interest.

Acknowledgements. The analyses presented in this study would not have been possible without the effort of all the individual researchers that enabled this study by providing freely available datasets in addition to their published work. Especially, we would like to thank Tomas Ferreira Domingues, Celso von Randow and Alessandro Carioca de Araújo for sharing their data with us. We would also like to thank the two anonymous referees for their rigorous reviews, which greatly enhanced the quality of the manuscript. Han Dolman and Thomas Janssen were funded by the Netherlands Earth System Science Centre (NESSC), financially supported by the Ministry of Education, Culture and Science (OCW; grant 024.002.001). Katrin Fleischer is funded by the Deutsche Forschungsgemeinschaft (DFG), grant no. RA 2060/5-1. Sebastiaan Luyssaert was funded through an Amsterdam Academic Alliance (AAA) fellowship.

Financial support. This research has been supported by the Netherlands Earth System Science Centre (grant no. 024.002.001) and the Deutsche Forschungsgemeinschaft (grant no. RA 2060/5-1).

Review statement. This paper was edited by Martin De Kauwe and reviewed by two anonymous referees.

\section{References}

Albert, L. P., Wu, J., Prohaska, N., de Camargo, P. B., Huxman, T. E., Tribuzy, E. S., Ivanov, V. Y., Oliveira, R. S., Garcia, S., Smith, M. N., Oliveira Junior, R. C., Restrepo-Coupe,
N., da Silva, R., Stark, S. C., Martins, G. A., Penha, D. V., and Saleska, S. R.: Age-dependent leaf physiology and consequences for crown-scale carbon uptake during the dry season in an Amazon evergreen forest, New Phytol., 219, 870-884, https://doi.org/10.1111/nph.15056, 2018.

Alexandre, D. Y.: Comportement hydrique au cours de la saison seche et place dans la succession de trois arbres guyanais: Trema micrantha, Goupia glabra et Eperua grandiflora, Ann. Sci. Forest, 48, 101-112, 1991.

Allen, C. D., Breshears, D. D., and McDowell, N. G.: On underestimation of global vulnerability to tree mortality and forest die-off from hotter drought in the Anthropocene, Ecosphere, 6, 1-55, https://doi.org/10.1890/ES15-00203.1, 2015.

Allen, M. T. and Pearcy, R. W.: Stomatal behavior and photosynthetic performance under dynamic light regimes in a seasonally dry tropical rain forest, Oecologia, 122, 470-478, https://doi.org/10.1007/s004420050968, 2000.

Aragão, L. E. O. C., Malhi, Y., Roman-Cuesta, R. M., Saatchi, S., Anderson, L. O., and Shimabukuro, Y. E.: Spatial patterns and fire response of recent Amazonian droughts, Geophys. Res. Lett., 34, L07701, https://doi.org/10.1029/2006GL028946, 2007.

Aragão, L. E. O. C., Anderson, L. O., Fonseca, M. G., Rosan, T. M., Vedovato, L. B., Wagner, F. H., Silva, C. V. J., Silva Junior, C. H. L., Arai, E., Aguiar, A. P., Barlow, J., Berenguer, E., Deeter, M. N., Domingues, L. G., Gatti, L., Gloor, M., Malhi, Y., Marengo, J. A., Miller, J. B., Phillips, O. L., and Saatchi, S.: 21st Century drought-related fires counteract the decline of Amazon deforestation carbon emissions, Nat. Commun., 9, 112, https://doi.org/10.1038/s41467-017-02771-y, 2018.

Araújo, A. C. de, Von Randow, R. de C. S., and Restrepo-Coupe, N.: Interactions Between Biosphere, Atmosphere and Human Land Use in the Amazon Basin, in: Interactions Between Biosphere, Atmosphere and Human Land Use in the Amazon Basin, 227, 149-169, 2016.

Baas, P., Ewers, F. W., Davis, S. D., and Wheeler, E. A.: Evolution of xylem physiology, in: The Evolution of Plant Physiology, edited by: Hemsley, A. R. and Poole, I., Academic Press, Oxford, 273-295, 2004.

Boisier, J. P., Ciais, P., Ducharne, A., and Guimberteau, M.: Projected strengthening of Amazonian dry season by constrained climate model simulations, Nat. Clim. Change, 5, 656-660, https://doi.org/10.1038/nclimate2658, 2015.

Bonal, D., Barigah, T. S., Granier, A., and Guehl, J. M.: Latestage canopy tree species with extremely low $\delta^{13} \mathrm{C}$ and high stomatal sensitivity to seasonal soil drought in the tropical rainforest of French Guiana, Plant Cell Environ., 23, 445-459, https://doi.org/10.1046/j.1365-3040.2000.00556.x, 2000a.

Bonal, D., Atger, C., Barigah, T. S., Ferhi, A. A. A., Guehl, J.-M. M., Ferry, B., Atger, C., Barigah, T. S., Bonal, D., Guehl, J.-M. M., Ferry, B., Atger, C., Barigah, T. S., Ferhi, A. A. A., Guehl, J.-M. M., and Ferry, B.: Water acquisition patterns of two wet tropical canopy tree species of French Guiana as inferred from (H2O)-O-18 extraction profiles, Ann. Forest Sci., 57, 717-724, https://doi.org/10.1051/forest:2000152, 2000b.

Bonal, D., Bosc, A., Ponton, S., Goret, J. Y., Burban, B. T., Gross, P., Bonnefond, J. M., Elbers, J., Longdoz, B., Epron, D., Guehl, J. M., and Granier, A.: Impact of severe dry season on net ecosystem exchange in the Neotropical rainfor- 
est of French Guiana, Glob. Change Biol., 14, 1917-1933, https://doi.org/10.1111/j.1365-2486.2008.01610.x, 2008.

Bonal, D., Burban, B., Stahl, C., Wagner, F., and Hérault, B.: The response of tropical rainforests to drought - lessons from recent research and future prospects, Ann. Forest Sci., 73, 27-44, https://doi.org/10.1007/s13595-015-0522-5, 2016.

Borchert, R.: Soil and stem water storage determine phenology and distribution of tropical dry forest trees, Ecology, 75, 1437-1449, https://doi.org/10.2307/1937467, 1994.

Borchert, R., Calle, Z., Strahler, A. H., Baertschi, A., Magill, R. E., Broadhead, J. S., Kamau, J., Njoroge, J., and Muthuri, C.: Insolation and photoperiodic control of tree development near the equator, New Phytol., 205, 7-13, https://doi.org/10.1111/nph.12981, 2015.

Bradley, A. V., Gerard, F. F., Barbier, N., Weedon, G. P., Anderson, L. O., Huntingford, C., Aragão, L. E. O. C., Zelazowski, P., and Arai, E.: Relationships between phenology, radiation and precipitation in the Amazon region, Glob. Change Biol., 17, 22452260, https://doi.org/10.1111/j.1365-2486.2011.02405.x, 2011.

Brando, P. M., Nepstad, D. C., Davidson, E. A., Trumbore, S. E., Ray, D., and Camargo, P.: Drought effects on litterfall, wood production and belowground carbon cycling in an Amazon forest: results of a throughfall reduction experiment, Philos. T. R. Soc. B, 363, 1839-1848, https://doi.org/10.1098/rstb.2007.0031, 2008.

Brando, P. M., Goetz, S. J., Baccini, A., Nepstad, D. C., Beck, P. S. A., and Christman, M. C.: Seasonal and interannual variability of climate and vegetation indices across the Amazon, P. Natl. Acad. Sci. USA, 107, 14685-14690, https://doi.org/10.1073/pnas.0908741107, 2010.

Breshears, D. D., Adams, H. D., Eamus, D., McDowell, N. G., Law, D. J., Will, R. E., Williams, A. P., and Zou, C. B.: The critical amplifying role of increasing atmospheric moisture demand on tree mortality and associated regional die-off, Front. Plant Sci., 4, p. 266, https://doi.org/10.3389/fpls.2013.00266, 2013.

Brienen, R. J. W., Helle, G., Pons, T. L., Guyot, J.-L., and Gloor, M.: Oxygen isotopes in tree rings are a good proxy for Amazon precipitation and El Nino-Southern Oscillation variability, P. Natl. Acad. Sci. USA, 109, 16957-16962, https://doi.org/10.1073/pnas.1205977109, 2012.

Brienen, R. J. W., Phillips, O. L., Feldpausch, T. R., Gloor, E., Baker, T. R., Lloyd, J., Lopez-Gonzalez, G., MonteagudoMendoza, A., Malhi, Y., Lewis, S. L., Vásquez Martinez, R., Alexiades, M., Álvarez Dávila, E., Alvarez-Loayza, P., Andrade, A., Aragaõ, L. E. O. C., Araujo-Murakami, A., Arets, E. J. M. M., Arroyo, L., Aymard C., G. A., Bánki, O. S., Baraloto, C., Barroso, J., Bonal, D., Boot, R. G. A., Camargo, J. L. C., Castilho, C. V., Chama, V., Chao, K. J., Chave, J., Comiskey, J. A., Cornejo Valverde, F., Da Costa, L., De Oliveira, E. A., Di Fiore, A., Erwin, T. L., Fauset, S., Forsthofer, M., Galbraith, D. R., Grahame, E. S., Groot, N., Hérault, B., Higuchi, N., Honorio Coronado, E. N., Keeling, H., Killeen, T. J., Laurance, W. F., Laurance, S., Licona, J., Magnussen, W. E., Marimon, B. S., Marimon-Junior, B. H., Mendoza, C., Neill, D. A., Nogueira, E. M., Núñez, P., Pallqui Camacho, N. C., Parada, A., Pardo-Molina, G., Peacock, J., Penã-Claros, M., Pickavance, G. C., Pitman, N. C. A., Poorter, L., Prieto, A., Quesada, C. A., Ramírez, F., Ramírez-Angulo, H., Restrepo, Z., Roopsind, A., Rudas, A., Salomaõ, R. P., Schwarz, M., Silva, N., Silva-Espejo, J. E., Silveira, M., Stropp, J., Tal- bot, J., Ter Steege, H., Teran-Aguilar, J., Terborgh, J., ThomasCaesar, R., Toledo, M., Torello-Raventos, M., Umetsu, R. K., Van Der Heijden, G. M. F., Van Der Hout, P., Guimarães Vieira, I. C., Vieira, S. A., Vilanova, E., Vos, V. A., and Zagt, R. J.: Longterm decline of the Amazon carbon sink, Nature, 519, 344-348, https://doi.org/10.1038/nature14283, 2015.

Brodribb, T. J., Holbrook, N. M., Edwards, E. J., and Gutiérrez, M. V.: Relations between stomatal closure, leaf turgor and xylem vulnerability in eight tropical dry forest trees, Plant Cell Environ., 26, 443-450, https://doi.org/10.1046/j.13653040.2003.00975.x, 2003.

Brum, M., López, J. G., Asbjornsen, H., Licata, J., Pypker, T., Sanchez, G., and Oiveira, R. S.: ENSO effects on the transpiration of eastern Amazon trees, Philos. T. R. Soc. B, 373, 20180085, https://doi.org/10.1098/rstb.2018.0085, 2018.

Brum, M., Vadeboncoeur, M. A., Ivanov, V., Asbjornsen, H., Saleska, S., Alves, L. F., Penha, D., Dias, J. D., Aragão, L. E. O. C., Barros, F., Bittencourt, P., Pereira, L., and Oliveira, R. S.: Hydrological niche segregation defines forest structure and drought tolerance strategies in a seasonal Amazon forest, J. Ecol., 107, 318-333, https://doi.org/10.1111/1365-2745.13022, 2019.

Buck, A. L.: New equations for computing vapour pressure and enhancement factor, J. Appl. Meteorol., 20, 1527-1532, 1981.

Buckley, T. N.: How do stomata respond to water status?, New Phytol., 224, 21-36, https://doi.org/10.1111/nph.15899, 2019.

Chambers, J. Q., Tribuzy, E. S., Toledo, L. C., Crispim, B. F., Santos, J., Araújo, A. C., Kruijt, B., Nobre, A. D., Trumbore, E., Higuchi, N., Dos Santos, J., Araújo, A. C., Kruijt, B., Nobre, A. D., and Trumbore, S. E.: Respiration from a Tropical Forest Ecosystem?: Partitioning of Sources and Low Carbon Use Efficiency, Ecol. Appl., 14, 72-88, https://doi.org/10.1890/01-6012, 2004.

Chave, J., Muller-Landau, H. C., Baker, T. R., Easdale, T. A., Hans Steege, T. E. R., and Webb, C. O.: Regional and phylogenetic variation of wood density across 2456 neotropical tree species, Ecol. Appl., 16, 2356-2367, https://doi.org/10.1890/10510761(2006)016[2356:RAPVOW]2.0.CO;2, 2006.

Chave, J., Coomes, D. A., Jansen, S., Lewis, S. L., Swenson, N. G., and Zanne, A. E.: Towards a worldwide wood economies spectrum, Ecol. Lett., 12, 351-366, https://doi.org/10.1111/j.14610248.2009.01285.x, 2009.

Chave, J., Navarrete, D., Almeida, S., Álvarez, E., Aragão, L. E. O. C., Bonal, D., Châtelet, P., Silva-Espejo, J. E., Goret, J.-Y., von Hildebrand, P., Jiménez, E., Patiño, S., Peñuela, M. C., Phillips, O. L., Stevenson, P., and Malhi, Y.: Regional and seasonal patterns of litterfall in tropical South America, Biogeosciences, 7, 43-55, https://doi.org/10.5194/bg-7-43-2010, 2010.

Choat, B., Brodribb, T. J., Brodersen, C. R., Duursma, R. A., López, R., and Medlyn, B. E.: Triggers of tree mortality under drought, Nature, 558, 531-539, https://doi.org/10.1038/s41586018-0240-x, 2018.

Christoffersen, B. O., Gloor, M., Fauset, S., Fyllas, N. M., Galbraith, D. R., Baker, T. R., Kruijt, B., Rowland, L., Fisher, R. A., Binks, O. J., Sevanto, S., Xu, C., Jansen, S., Choat, B., Mencuccini, M., Mcdowell, N. G., Meir, P., Baker, R., Kruijt, B., Rowland, L., Fisher, R. A., Binks, O. J., Sevanto, S., Xu, C., Jansen, S., Choat, B., Mencuccini, M., Mcdowell, N. G., Meir, P., Baker, T. R., Kruijt, B., Rowland, L., Fisher, R. A., Binks, O. J., Sevanto, S., Xu, C., Jansen, S., Choat, B., Mencuccini, M., Mcdowell, N. 
G., and Meir, P.: Linking hydraulic traits to tropical forest function in a size-structured and trait-driven model (TFS v.1-Hydro), Geosci. Model Dev., 9, 4227-4255, https://doi.org/10.5194/gmd9-4227-2016, 2016.

Clark, D. A., Piper, S. C., Keeling, C. D., and Clark, D. B.: Tropical rain forest tree growth and atmospheric carbon dynamics linked to interannual temperature variation during 1984-2000, P. Natl. Acad. Sci. USA, 100, 5852-5857, https://doi.org/10.1073/pnas.0935903100, 2003.

Clark, D. A., Clark, D. B., and Letcher, S. G.: Three decades of annual growth, mortality, physical condition, and microsite for ten tropical rainforest tree species, Ecology, 99, 1901, https://doi.org/10.1002/ecy.2394, 2018.

Coelho, C. A. S., Cavalcanti, I. A. F., Costa, S. M. S., Freitas, S. R., Ito, E. R., Luz, G., Santos, A. F., Nobre, C. A., Marengo, J. A., and Pezza, A. B.: Climate diagnostics of three major drought events in the Amazon and illustrations of their seasonal precipitation predictions, Meteorol. Appl., 19, 237-255, https://doi.org/10.1002/met.1324, 2012.

Condit, R., Hubbell, S. P., and Foster, R. B.: Mortality rates of 205 neotropical tree and shrub species and the impact of a severe drought, Ecol. Monogr., 65, 419-439, https://doi.org/10.2307/2963497, 1995.

Costa, M. H. and Pires, G. F.: Effects of Amazon and Central Brazil deforestation scenarios on the duration of the dry season in the arc of deforestation, Int. J. Climatol., 30, 1970-1979, https://doi.org/10.1002/joc.2048, 2010.

Cox, P. M., Betts, R. a, Jones, C. D., Spall, S., and Totterdell, I. J.: Acceleration of global warming due to carbon-cycle feedbacks in a coupled climate model, Nature, 408, 184-187, https://doi.org/10.1038/35041539, 2000.

Cox, P. M., Betts, R. A., Collins, M., Harris, P. P., Huntingford, C., and Jones, C. D.: Amazonian forest dieback under climatecarbon cycle projections for the 21 st century, Theor. Appl. Climatol., 78, 137-156, https://doi.org/10.1007/s00704-004-00494, 2004.

da Costa, A. C. L., Galbraith, D., Almeida, S., Portela, B. T. T., da Costa, M., de Athaydes Silva Junior, J., Braga, A. P., de Gon??alves, P. H. L., de Oliveira, A. A., Fisher, R., Phillips, O. L., Metcalfe, D. B., Levy, P., and Meir, P.: Effect of 7 yr of experimental drought on vegetation dynamics and biomass storage of an eastern Amazonian rainforest, New Phytol., 187, 579-591, https://doi.org/10.1111/j.1469-8137.2010.03309.x, 2010.

da Costa, A. C. L., Rowland, L., Oliveira, R. S., Oliveira, A. A. R., Binks, O. J., Salmon, Y., Vasconcelos, S. S., Junior, J. A. S., Ferreira, L. V., Poyatos, R., Mencuccini, M., and Meir, P.: Stand dynamics modulate water cycling and mortality risk in droughted tropical forest, Glob. Change Biol., 24, 249-258, https://doi.org/10.1111/gcb.13851, 2018.

da Rocha, H. Da, Goulden, M., Miller, S. D., Menton, M., Pinto, L. B., de Freitas, H. C., and Figueira, A. M. S.: Seasonality of water and heat fluxes over a tropical forest in eastern Amazonia, Ecol. Appl., 14, 22-32, https://doi.org/10.1890/02-6005, 2004.

Davidson, E., Lefebvre, P. A., Brando, P. M., Ray, D. M., Trumbore, S. E., Solorzano, L. A., Ferreira, J. N., da Bustamante, M. M. C., and Nepstad, D. C.: Carbon inputs and water uptake in deep soils of an eastern amazon forest, Forest Sci., 57, 51-58, https://doi.org/10.1016/j.cognition.2008.05.007, 2011.
Davidson, E. A., de Araújo, A. C., Artaxo, P., Balch, J. K., Brown, I. F., C. Bustamante, M. M., Coe, M. T., DeFries, R. S., Keller, M., Longo, M., Munger, J. W., Schroeder, W., Soares-Filho, B. S., Souza, C. M., and Wofsy, S. C.: The Amazon basin in transition, Nature, 481, 321-328, https://doi.org/10.1038/nature10717, 2012.

Debortoli, N. S., Dubreuil, V., Hirota, M., Filho, S. R., Lindoso, D. P., and Nabucet, J.: Detecting deforestation impacts in Southern Amazonia rainfall using rain gauges, Int. J. Climatol., 37, 28892900, https://doi.org/10.1002/joc.4886, 2017.

De Guzman, M. E., Santiago, L. S., Schnitzer, S. A., and Álvarez-Cansino, L.: Trade-offs between water transport capacity and drought resistance in neotropical canopy liana and tree species, Tree Physiol., 37, 1404-1414, https://doi.org/10.1093/treephys/tpw086, 2017.

De Kauwe, M. G., Medlyn, B. E., Knauer, J., and Williams, C. A.: Ideas and perspectives: how coupled is the vegetation to the boundary layer?, Biogeosciences, 14, 4435-4453, https://doi.org/10.5194/bg-14-4435-2017, 2017.

Dewar, R., Mauranen, A., Mäkelä, A., Hölttä, T., Medlyn, B., and Vesala, T.: New insights into the covariation of stomatal, mesophyll and hydraulic conductances from optimization models incorporating nonstomatal limitations to photosynthesis, New Phytol., 217, 571-585, https://doi.org/10.1111/nph.14848, 2018.

Dickman, L. T., McDowell, N. G., Grossiord, C., Collins, A. D., Wolfe, B. T., Detto, M., Wright, S. J., Medina-Vega, J. A., Goodsman, D., Rogers, A., Serbin, S. P., Wu, J., Ely, K. S., Michaletz, S. T., Xu, C., Kueppers, L., and Chambers, J. Q.: Homoeostatic maintenance of nonstructural carbohydrates during the 2015-2016 El Niño drought across a tropical forest precipitation gradient, Plant Cell Environ., 42, 1705-1714, https://doi.org/10.1111/pce.13501, 2019.

Domingues, T. F., Martinelli, L. A., and Ehleringer, J. R.: Seasonal patterns of leaf-level photosynthetic gas exchange in an eastern Amazonian rain forest, Plant Ecol. Divers., 7, 189-203, https://doi.org/10.1080/17550874.2012.748849, 2014.

Doughty, C. E.: An In Situ Leaf and Branch Warming Experiment in the Amazon, Biotropica, 43, 658-665, https://doi.org/10.1111/j.1744-7429.2010.00746.x, 2011.

Doughty, C. E. and Goulden, M. L.: Are tropical forests near a high temperature threshold?, J. Geophys. Res.-Biogeo., 114, 112, https://doi.org/10.1029/2007JG000632, 2009a.

Doughty, C. E. and Goulden, M. L.: Seasonal patterns of tropical forest leaf area index and $\mathrm{CO}_{2}$ exchange, J. Geophys. Res.-Biogeo., 114, G1, https://doi.org/10.1029/2007JG000590, 2009b.

Doughty, C. E., Malhi, Y., Araujo-murakami, A., Metcalfe, D. B., Silva-Espejo, J. E., Arroyo, L., Heredia, J. P., Pardo-Toledo, E., Mendizabal, L. M., Rojas-Landivar, V. D., Vega-Martinez, M., Flores-Valencia, M., Sibler-Rivero, R., Moreno-Vare, L., Jessica Viscarra, L., Chuviru-Castro, T., Osinaga-Becerra, M., Ledezma, R., Javier, E., Arroyo, L., Heredia, J. P., Pardo-Toledo, E., Mendizabal, L. M., and Victor, D.: Allocation trade-offs dominate the response of tropical forest growth to seasonal and interannual drought, Ecology, 95, 1-6, https://doi.org/10.1890/131507.1, 2014.

Doughty, C. E., Metcalfe, D. B., Girardin, C. A. J., Amézquita, F. F., Cabrera, D. G., Huasco, W. H., Silva-Espejo, J. E., Araujo-Murakami, A., da Costa, M. C., Rocha, W., Feldpausch, 
T. R., Mendoza, A. L. M., da Costa, A. C. L., Meir, P., Phillips, O. L., and Malhi, Y.: Drought impact on forest carbon dynamics and fluxes in Amazonia, Nature, 519, 78-82, https://doi.org/10.1038/nature14213, 2015.

Doughty, C. E., Goldsmith, G. R., Raab, N., Girardin, C. A. J., Farfan-Amezquita, F., Huaraca-Huasco, W., Silva-Espejo, J. E., Araujo-Murakami, A., da Costa, A. C. L., Rocha, W., Galbraith, D., Meir, P., Metcalfe, D. B., and Malhi, Y.: What controls variation in carbon use efficiency among Amazonian tropical forests?, Biotropica, 50, 16-25, https://doi.org/10.1111/btp.12504, 2017.

Drake, J. E., Power, S. A., Duursma, R. A., Medlyn, B. E., Aspinwall, M. J., Choat, B., Creek, D., Eamus, D., Maier, C., Pfautsch, S., Smith, R. A., Tjoelker, M. G., and Tissue, D. T.: Stomatal and non-stomatal limitations of photosynthesis for four tree species under drought: A comparison of model formulations, Agr. Forest Meteorol., 247, 454-466, https://doi.org/10.1016/j.agrformet.2017.08.026, 2017.

Dünisch, O. and Morais, R. R.: Regulation of xylem sap flow in an evergreen, a semi-deciduous, and a deciduous Meliaceae species from the Amazon, Trees-Struct. Funct., 16, 404-416, https://doi.org/10.1007/s00468-002-0182-6, 2002.

ECMWF: ERA5 ECMWF, ERA5, available at: https://www.ecmwf. int/en/forecasts/datasets/reanalysis-datasets/era5, last access: 25 October 2019.

Erfanian, A., Wang, G., and Fomenko, L.: Unprecedented drought over tropical South America in 2016: Significantly under-predicted by tropical SST, Sci. Rep., 7, 22-24, https://doi.org/10.1038/s41598-017-05373-2, 2017.

Esquivel-Muelbert, A., Galbraith, D., Dexter, K. G., Baker, T. R., Lewis, S. L., Meir, P., Rowland, L., da Costa, A. C. L., Nepstad, D., and Phillips, O. L.: Biogeographic distributions of neotropical trees reflect their directly measured drought tolerances, Sci. Rep., 7, 8334, https://doi.org/10.1038/s41598-01708105-8, 2017a.

Esquivel-Muelbert, A., Baker, T. R., Dexter, K. G., Lewis, S. L., ter Steege, H., Lopez-Gonzalez, G., Monteagudo Mendoza, A., Brienen, R., Feldpausch, T. R., Pitman, N., Alonso, A., van der Heijden, G., Peña-Claros, M., Ahuite, M., Alexiaides, M., Álvarez Dávila, E., Murakami, A. A., Arroyo, L., Aulestia, M., Balslev, H., Barroso, J., Boot, R., Cano, A., Chama Moscoso, V., Comiskey, J. A., Cornejo, F., Dallmeier, F., Daly, D. C., Dávila, N., Duivenvoorden, J. F., Duque Montoya, A. J., Erwin, T., Di Fiore, A., Fredericksen, T., Fuentes, A., García-Villacorta, R., Gonzales, T., Guevara Andino, J. E., Honorio Coronado, E. N., Huamantupa-Chuquimaco, I., Killeen, T. J., Malhi, Y., Mendoza, C., Mogollón, H., Jørgensen, P. M., Montero, J. C., Mostacedo, B., Nauray, W., Neill, D., Vargas, P. N., Palacios, S., Palacios Cuenca, W., Pallqui Camacho, N. C., Peacock, J., Phillips, J. F., Pickavance, G., Quesada, C. A., Ramírez-Angulo, H., Restrepo, Z., Reynel Rodriguez, C., Paredes, M. R., Sierra, R., Silveira, M., Stevenson, P., Stropp, J., Terborgh, J., Tirado, M., Toledo, M., Torres-Lezama, A., Umaña, M. N., Urrego, L. E., Vasquez Martinez, R., Gamarra, L. V., Vela, C. I. A., Vilanova Torre, E., Vos, V., von Hildebrand, P., Vriesendorp, C., Wang, O., Young, K. R., Zartman, C. E., and Phillips, O. L.: Seasonal drought limits tree species across the Neotropics, Ecography (Cop.)., 40, 618-629, https://doi.org/10.1111/ecog.01904, 2017b.

Exbrayat, J.-F., Liu, Y. Y., and Williams, M.: Impact of deforestation and climate on the Amazon Basin's above- ground biomass during 1993-2012, Sci. Rep., 7, 15615, https://doi.org/10.1038/s41598-017-15788-6, 2017.

Feldpausch, T. R., Phillips, O. L., Brienen, R. J. W., Gloor, E., Lloyd, J., Malhi, Y., Alarcón, A., Dávila, E. Á., Andrade, A., Aragao, L. E. O. C., Arroyo, L., Aymard, G. A. C., Baker, T. R., Baraloto, C., Barroso, J., Bonal, D., Castro, W., Chama, V., Chave, J., Domingues, T. F., Fauset, S., Groot, N., Coronado, E. H., Laurance, S., Laurance, W. F., Lewis, S. L., Licona, J. C., Marimon, B. S., Bautista, C. M., Neill, D. A., Oliveira, E. A., Santos, C. O., Camacho, N. C. P., Prieto, A., Quesada, C. A., Ramírez, F., Rudas, A., Saiz, G., Salomão, R. P., Silveira, M., Steege, H., Stropp, J., Terborgh, J., Heijden, G. M. F., Martinez, R. V., Vilanova, E., and Vos, V. A.: Amazon forest response to repeated droughts, Global Biogeochem. Cy., 30, 964-982, 2016.

Felsemburgh, C. A.: Respostas fotossintéticas à variação da temperatura foliar do dossel na Flona do Tapajós, Universidade de São Paulo, PA, 2009.

Fisher, R. A., Williams, M., Do Vale, L. R., Da Costa, A. L., and Meir, P.: Evidence from Amazonian forests is consistent with a model of isohydric control of leaf water potential, Plant Cell Environ., 29, 151-165, 2006.

Fontes, C. G., Dawson, T. E., Jardine, K., McDowell, N., Gimenez, B. O., Anderegg, L., Negrón-Juárez, R., Higuchi, N., Fine, P. V. A., Araújo, A. C., and Chambers, J. Q.: Dry and hot: the hydraulic consequences of a climate change-type drought for Amazonian trees, Philos. T. R. Soc. Lond. B., 373, 1760, https://doi.org/10.1098/rstb.2018.0209, 2018.

Fu, R., Yin, L., Li, W., Arias, P. A., Dickinson, R. E., Huang, L., Chakraborty, S., Fernandes, K., Liebmann, B., Fisher, R., and Myneni, R. B.: Increased dry-season length over southern Amazonia in recent decades and its implication for future climate projection, P. Natl. Acad. Sci. USA, 110, 18110-18115, https://doi.org/10.1073/pnas.1302584110, 2013.

Gatti, L. V, Gloor, M., Miller, J. B., Doughty, C. E., Malhi, Y., Domingues, L. G., Basso, L. S., Martinewski, A., Correia, C. S. C., Borges, V. F., Freitas, S., Braz, R., Anderson, L. O., Rocha, H., Grace, J., Phillips, O. L., and Lloyd, J.: Drought sensitivity of Amazonian carbon balance revealed by atmospheric measurements, Nature, 506, 76-80, https://doi.org/10.1038/nature12957, 2014.

Girardin, C. A. J., Malhi, Y., Doughty, C. E., Metcalfe, D. B., Meir, P., Aguila-Pasquel, J., Araujo-Murakami, A., Costa, A. C. L., Silva-Espejo, J. E., Amézquita, F. F., Rowland, L., del Aguila-Pasquel, J., Araujo-Murakami, A., da Costa, A. C. L., Silva-Espejo, J. E., Farfán Amézquita, F., Rowland, L., AguilaPasquel, J., Araujo-Murakami, A., Costa, A. C. L., Silva-Espejo, J. E., Amézquita, F. F., and Rowland, L.: Seasonal trends of Amazonian rainforest phenology, net primary productivity, and carbon allocation, Global Biogeochem. Cy., 30, 700-715, 2016.

Goldstein, G., Andrade, J. L., Meinzer, F. C., Holbrook, N. M., Cavelier, J., Jackson, P., and Celis, A.: Stem water storage and diurnal patterns of water use in tropical forest canopy trees, Plant. Cell Environ., 21, 397-406, https://doi.org/10.1046/j.13653040.1998.00273.x, 1998.

Gonçalves, N. B., Lopes, A. P., Dalagnol, R., Wu, J., Pinho, D. M., and Nelson, B. W.: Both near-surface and satellite remote sensing confirm drought legacy effect on tropical forest leaf phenology after 2015/2016 ENSO drought, Remote Sens. Environ., 237, 111489, https://doi.org/10.1016/j.rse.2019.111489, 2020. 
Goulden, M. L., Miller, S. D., Da Rocha, H. R., Menton, M. C., De Freitas, H. C., E Silva Figueira, A. M., and Dias De Sousa, C. A.: Diel and seasonal patterns of tropical forest $\mathrm{CO}_{2}$ exchange, Ecol. Appl., 14, 42-54, https://doi.org/10.1890/02-6008, 2004.

Graham, E. A., Mulkey, S. S., Kitajima, K., Phillips, N. G., and Wright, S. J.: Cloud cover limits net $\mathrm{CO}_{2}$ uptake and growth of a rainforest tree during tropical rainy seasons, P. Natl. Acad. Sci. USA, 100, 572-576, https://doi.org/10.1073/pnas.0133045100, 2003.

Granier, A., Huc, R., and Colin, F.: Transpiration and stomatal conductance of 2 rainforest species growing in plantations (Simarouba amara and Goupia glabra) in French-Guyana, Ann. Forest Sci., 49, 17-24, 1992.

Grothe, P. R., Cobb, K. M., Liguori, G., Di Lorenzo, E., Capotondi, A., Lu, Y., Cheng, H., Edwards, R. L., Southon, J. R., Santos, G. M., Deocampo, D. M., Lynch-Stieglitz, J., Chen, T., Sayani, H. R., Thompson, D. M., Conroy, J. L., Moore, A. L., Townsend, K., Hagos, M., O'Connor, G., and Toth, L. T.: Enhanced El Niño-Southern Oscillation variability in recent decades, Geophys. Res. Lett., 47, GL083906, https://doi.org/10.1029/2019gl083906, 2019.

Harper, A., Baker, I. T., Denning, A. S., Randall, D. A., Dazlich, D., and Branson, M.: Impact of evapotranspiration on dry season climate in the Amazon forest, J. Clim., 27, 574-591, https://doi.org/10.1175/JCLI-D-13-00074.1, 2014.

Hedges, L. V. and Gurevitch, J.: 1, 2 AND PETER S. CURTIS3 and Curtis, P. S.: The meta-analysis of response ratios in experimental ecology, Ecology, $\quad 80, \quad 1150-1156, \quad$ https://doi.org/10.1890/00129658(1999)080[1150:TMAORR]2.0.CO;2, 1999.

Hofhansl, F., Kobler, J., Ofner, J., Drage, S., Pölz, E. M., and Wanek, W.: Sensitivity of tropical forest aboveground productivity to climate anomalies in SW Costa Rica, Global Biogeochem. Cy., 28, 1437-1454, https://doi.org/10.1002/2014GB004934, 2014.

Hogan, K. P., Smith, A. P., Samaniego, M., Smith, A. P., Samaniego, M., and Mechanism, B.: Gas Exchange in Six Tropical Semi-Deciduous Forest Canopy Tree Species During the Wet and Dry Seasons, Biotropica, 27, 324-333, https://doi.org/10.2307/2388918, 1995.

Huc, R., Ferhi, A., and Guehl, J. M.: Pioneer and late stage tropical rainforest tree species (French Guiana) growing under common conditions differ in leaf gas exchange regulation, carbon isotope discrimination and leaf water potential, Oecologia, 99, 297-305, https://doi.org/10.1007/BF00627742, 1994.

Hutyra, L. R., Munger, J. W., Saleska, S. R., Gottlieb, E., Daube, B. C., Dunn, A. L., Amaral, D. F., de Camargo, P. B., and Wofsy, S. C.: Seasonal controls on the exchange of carbon and water in an Amazonian rain forest, J. Geophys. Res.-Biogeo., 112, 1-16, https://doi.org/10.1029/2006JG000365, 2007.

Janssen, T.: Replication Data for: Drought resistance increases from the individual to the ecosystem level in highly diverse Neotropical rainforest: a meta-analysis of leaf, tree and ecosystem responses to drought, available at: https://hdl.handle.net/10411/ 41KALW (last access: 14 May 2020), DataverseNL, 2020.

Janssen, T. A. J., Hölttä, T., Fleischer, K., Naudts, K., and Dolman, H.: Wood allocation trade-offs between fiber wall, fiber lumen, and axial parenchyma drive drought resis- tance in neotropical trees, Plant. Cell Environ., 43, 965-980, https://doi.org/10.1111/pce.13687, 2020.

Jarvis, P. G. and Mcnaughton, K. G.: Stomatal Control of Transpiration: Scaling Up from Leaf to Region, Adv. Ecol. Res., 15, 1-49, https://doi.org/10.1016/S0065-2504(08)60119-1, 1986.

Jiménez-Muñoz, J. C., Mattar, C., Barichivich, J., SantamaríaArtigas, A., Takahashi, K., Malhi, Y., Sobrino, J. A., and Schrier, G. van der: Record-breaking warming and extreme drought in the Amazon rainforest during the course of El Niño 2015-2016, Sci. Rep., 6, 33130, https://doi.org/10.1038/srep33130, 2016.

Jung, M., Reichstein, M., Ciais, P., Seneviratne, S. I., Sheffield, J., Goulden, M. L., Bonan, G., Cescatti, A., Chen, J., De Jeu, R., Dolman, A. J., Eugster, W., Gerten, D., Gianelle, D., Gobron, N., Heinke, J., Kimball, J., Law, B. E., Montagnani, L., Mu, Q., Mueller, B., Oleson, K., Papale, D., Richardson, A. D., Roupsard, O., Running, S., Tomelleri, E., Viovy, N., Weber, U., Williams, C., Wood, E., Zaehle, S., and Zhang, K.: Recent decline in the global land evapotranspiration trend due to limited moisture supply, Nature, 467, 951-954, https://doi.org/10.1038/nature09396, 2010.

Khanna, J., Medvigy, D., Fueglistaler, S., and Walko, R.: Regional dry-season climate changes due to three decades of Amazonian deforestation, Nat. Clim. Change, 7, 200-204, https://doi.org/10.1038/nclimate3226, 2017.

Körner, C. and Basel, M. L.: Growth Controls Photosynthesis Mostly, Nov. Acta Leopoldina, 283, 273-283, 2013.

Krepkowski, J., Bräuning, A., Gebrekirstos, A., and Strobl, S.: Cambial growth dynamics and climatic control of different tree life forms in tropical mountain forest in Ethiopia, Trees, 25, 5970, https://doi.org/10.1007/s00468-010-0460-7, 2011.

Kunert, N., Schwendenmann, L., and Hölscher, D.: Seasonal dynamics of tree sap flux and water use in nine species in Panamanian forest plantations, Agr. Forest Meteorol., 150, 411-419, https://doi.org/10.1016/j.agrformet.2010.01.006, 2010.

Lachenbruch, B. and Mcculloh, K. A.: Traits, properties, and performance: How woody plants combine hydraulic and mechanical functions in a cell, tissue, or whole plant, New Phytol., 204, 747764, https://doi.org/10.1111/nph.13035, 2014.

Lajeunesse, M. J.: On the meta-analysis of response ratios for studies with correlated and multi-group designs, Ecology, 92, 20492055, https://doi.org/10.1890/11-0423.1, 2011.

Lee, J.-E., Frankenberg, C., van der Tol, C., Berry, J. A., Guanter, L., Boyce, C. K., Fisher, J. B., Morrow, E., Worden, J. R., Asefi, S., Badgley, G., and Saatchi, S.: Forest productivity and water stress in Amazonia: observations from GOSAT chlorophyll fluorescence, Proc. R. Soc. B, 280, 1761, https://doi.org/10.1098/rspb.2013.0171, 2013.

Leitold, V., Morton, D. C., Longo, M., dos-Santos, M. N., Keller, M., and Scaranello, M.: El Niño drought increased canopy turnover in Amazon forests, New Phytol., 219, 959-971, https://doi.org/10.1111/nph.15110, 2018.

Lloyd, J. and Farquhar, G. D.: Effects of rising temperatures and $\left[\mathrm{CO}_{2}\right]$ on the physiology of tropical forest trees, Philos. T. R. Soc. B, 363, 1811-1817, https://doi.org/10.1098/rstb.2007.0032, 2008.

Love, D. M. and Sperry, J. S.: In situ embolism induction reveals vessel refilling in a natural aspen stand, Tree Physiol., 38, 10061015, https://doi.org/10.1093/treephys/tpy007, 2018. 
Machado, J. L. and Tyree, M. T.: Patterns of hydraulic architecture and water relations of two tropical canopy trees with contrasting leaf phenologies: Ochroma pyramidale and Pseudobombax septenatum, Tree Physiol., 14, 219-240, https://doi.org/10.1093/treephys/14.3.219, 1994.

Malhi, Y., Aragao, L. E. O. C., Galbraith, D., Huntingford, C., Fisher, R., Zelazowski, P., Sitch, S., McSweeney, C., and Meir, P.: Exploring the likelihood and mechanism of a climate-change-induced dieback of the Amazon rainforest, P. Natl. Acad. Sci. USA, 106, 20610-20615, https://doi.org/10.1073/pnas.0804619106, 2009.

Maréchaux, I., Bartlett, M. K., Sack, L., Baraloto, C., Engel, J., Joetzjer, E., and Chave, J.: Drought tolerance as predicted by leaf water potential at turgor loss point varies strongly across species within an Amazonian forest, Funct. Ecol., 29, 12681277, https://doi.org/10.1111/1365-2435.12452, 2015.

Maréchaux, I., Bonal, D., Bartlett, M. K., Burban, B., Coste, S., Courtois, E. A., Dulormne, M., Goret, J.-Y. Y., Mira, E., Mirabel, A., Sack, L., Stahl, C., and Chave, J.: Dry-season decline in tree sapflux is correlated with leaf turgor loss point in a tropical rainforest, Funct. Ecol., 32, 2285-2297, https://doi.org/10.1111/1365-2435.13188, 2018.

Marengo, J. A., Nobre, C. A., Tomasella, J., Oyama, M. D., de Oliveira, G. S., de Oliveira, R., Camargo, H., Alves, L. M., and Brown, I. F.: The drought of Amazonia in 2005, J. Clim., 21, 495-516, https://doi.org/10.1175/2007JCLI1600.1, 2008.

Marengo, J. A., Ambrizzi, T., da Rocha, R. P., Alves, L. M., Cuadra, S. V., Valverde, M. C., Torres, R. R., Santos, D. C., and Ferraz, S. E. T.: Future change of climate in South America in the late twenty-first century: Intercomparison of scenarios from three regional climate models, Clim. Dynam., 35, 1089-1113, https://doi.org/10.1007/s00382-009-0721-6, 2010.

Marengo, J. A., Tomasella, J., Alves, L. M., Soares, W. R., and Rodriguez, D. A.: The drought of 2010 in the context of historical droughts in the Amazon region, Geophys. Res. Lett., 38, 12, https://doi.org/10.1029/2011GL047436, 2011.

Markesteijn, L., Poorter, L., Paz, H., Sack, L., and Bongers, F.: Ecological differentiation in xylem cavitation resistance is associated with stem and leaf structural traits, Plant Cell Environ., 34, 137148, https://doi.org/10.1111/j.1365-3040.2010.02231.x, 2011a.

Markesteijn, L., Poorter, L., Bongers, F., Paz, H., and Sack, L.: Hydraulics and life history of tropical dry forest tree species: coordination of species' drought and shade tolerance, New Phytol., 191, 480-495, https://doi.org/10.1111/j.14698137.2011.03708.x, 2011b.

Martin-StPaul, N., Delzon, S., and Cochard, H.: Plant resistance to drought depends on timely stomatal closure, Ecol. Lett., 20, 1437-1447, https://doi.org/10.1111/ele.12851, 2017.

Mcdowell, N., Pockman, W. T., Allen, C. D., Breshears, D. D., Cobb, N., Kolb, T., Plaut, J., Sperry, J., West, A., Williams, D. G., Yepez, E. A., Mcdowell, N., Pockman, W. T., Allen, C. D., David, D., Mcdowell, N., Cobb, N., Kolb, T., Plaut, J., and Sperry, J.: Mechanisms of Plant Survival and Mortality during Drought: Why Do Some Plants Survive while Others Succumb to Drought, Wiley on behalf of the New Phytologist Trust Stable, New Phytol., 178, 719-739, 2008.

Meinzer, C. F., Andrade, L. J., Goldstein, G., Holbrook, M. N., Cavelier, J., and Wright, J. S.: Partitioning of soil water among canopy trees in a seasonally dry tropical forest, Oecologia, 121, 293-301, https://doi.org/10.1007/s004420050931, 1999.

Meinzer, F. C., Goldstein, G., Jackson, P., Holbrook, N. M., Gutiérrez, M. V., and Cavelier, J.: Environmental and physiological regulation of transpiration in tropical forest gap species: the influence of boundary layer and hydraulic properties, Oecologia, 101, 514-522, https://doi.org/10.1007/BF00329432, 1995.

Meinzer, F. C., Andrade, J. L., Goldstein, G., Holbrook, N. M., Cavelier, J., and Jackson, P.: Control of transpiration from the upper canopy of a tropical forest: The role of stomatal, boundary layer and hydraulic architecture components, Plant Cell Environ., 20, 1242-1252, https://doi.org/10.1046/j.1365-3040.1997.d0126.x, 1997.

Meinzer, F. C., James, S. A., Goldstein, G., and Woodruff, D.: Whole-tree water transport scales with sapwood capacitance in tropical forest canopy trees, Plant Cell Environ., 26, 1147-1155, https://doi.org/10.1046/j.1365-3040.2003.01039.x, 2003.

Meinzer, F. C., James, S. A., and Goldstein, G.: Dynamics of transpiration, sap flow and use of stored water in tropical forest canopy trees, Tree Physiol., 24, 901-909, https://doi.org/10.1093/treephys/24.8.901, 2004.

Meinzer, F. C., Campanello, P. I., Domec, J. C., Gatti, M. G., Goldstein, G., Villalobos-Vega, R., and Woodruff, D. R.: Constraints on physiological function associated with branch architecture and wood density in tropical forest trees, Tree Physiol., 28, 16091617, https://doi.org/10.1093/treephys/28.11.1609, 2008a.

Meinzer, F. C., Woodruff, D. R., Domec, J. C., Goldstein, G., Campanello, P. I., Gatti, M. G., and Villalobos-Vega, R.: Coordination of leaf and stem water transport properties in tropical forest trees, Oecologia, 156, 31-41, https://doi.org/10.1007/s00442008-0974-5, 2008b.

Meir, P., Brando, P. M., Nepstad, D. C., Vasconcelos, S. S. de, Costa, A. C. L. da, Davidson, E. A., Almeida, S. S. de, Fisher, R. A., Sotta, E. D., Zarin, D. J., and Cardinot, G.: The effects of drought on Amazonian rain forests, Amaz. Glob. Change, 186, 429-449, https://doi.org/10.1029/2009GM000882, 2009.

Meir, P., Mencuccini, M., Binks, O., Da Costa, A. L., Ferreira, L., and Rowland, L.: Short-term effects of drought on tropical forest do not fully predict impacts of repeated or long-term drought: Gas exchange versus growth, Philos. T. R. Soc. B, 373, 1760, https://doi.org/10.1098/rstb.2017.0311, 2018.

Metcalfe, D. B., Meir, P., Aragão, L. E. O. C., Costa, A. C. L., Braga, A. P., Gonçalves, P. H. L., Athaydes Silva Junior, J., Almeida, S. S., Dawson, L. A., Malhi, Y., and Williams, M.: The effects of water availability on root growth and morphology in an Amazon rainforest, Plant Soil, 311, 189-199, https://doi.org/10.1007/s11104-008-9670-9, 2008.

Muller, B., Pantin, F., Génard, M., Turc, O., Freixes, S., Piques, M., and Gibon, Y.: Water deficits uncouple growth from photosynthesis, increase $\mathrm{C}$ content, and modify the relationships between $\mathrm{C}$ and growth in sink organs, J. Exp. Bot., 62, 1715-1729, https://doi.org/10.1093/jxb/erq438, 2011.

Nepstad, D. C.: The effects of partial throughfall exclusion on canopy processes, aboveground production, and biogeochemistry of an Amazon forest, J. Geophys. Res., 107, D20 LBA-53, https://doi.org/10.1029/2001jd000360, 2002.

Nepstad, D. C., de Carvalho, C. R., Davidson, E. A., Jipp, P. H., Lefebvre, P. A., Negreiros, G. H., da Silva, E. D., Stone, T. A., Trumbore, S. E., and Vieira, S.: The role of deep roots in the hy- 
drological and carbon cycles of Amazonian forests and pastures, Nature, 372, 666-669, https://doi.org/10.1038/372666a0, 1994.

Oliva Carrasco, L., Bucci, S. J., Di Francescantonio, D., Lezcano, O. A., Campanello, P. I., Scholz, F. G., Rodriguez, S., Madanes, N., Cristiano, P. M., Hao, G. Y. G.-Y., Holbrook, N. M., Goldstein, G., Rodríguez, S., Madanes, N., Cristiano, P. M., Hao, G. Y. G.-Y., Holbrook, N. M., and Goldstein, G.: Water storage dynamics in the main stem of subtropical tree species differing in wood density, growth rate and life history traits, Tree Physiol., 35, 354-365, https://doi.org/10.1093/treephys/tpu087, 2015.

Olson, D. M., Dinerstein, E., Wikramanayake, E. D., Burgess, N. D., Powell, G. V. N., Underwood, E. C., D'amico, J. A., Itoua, I., Strand, H. E., Morrison, J. C., Loucks, C. J., Allnutt, T. F., Ricketts, T. H., Kura, Y., Lamoreux, J. F., Wettengel, W. W., Hedao, P., and Kassem, K. R.: Terrestrial Ecoregions of the World: A New Map of Life on Earth, Bioscience, 51, 933-938, https://doi.org/10.1641/00063568(2001)051[0933:teotwa]2.0.co;2, 2001.

Panisset, J., Libonati, R., Gouveia, C. M. P., Machado-Silva, F., França, D. A., França, J. R. A., and Peres, L. F.: Contrasting patterns of most extreme drought episodes of 2005, 2010 and 2015 in the Amazon Basin, Int. J. Climatol., 38, 1096-1104, https://doi.org/10.1002/joc.5224, 2017.

Patiño, S., Fyllas, N. M., Baker, T. R., Paiva, R., Quesada, C. A., Santos, A. J. B., Schwarz, M., Ter Steege, H., Phillips, O. L., and Lloyd, J.: Coordination of physiological and structural traits in Amazon forest trees, Biogeosciences, 9, 775-801, https://doi.org/10.5194/bg-9-775-2012, 2012.

Phillips, N., Bond, B. J., and Ryan, M. G.: Gas exchange and hydraulic properties in the crowns of two tree species in a Panamanian moist forest, Trees-Struct. Funct., 15, 123-130, https://doi.org/10.1007/s004680000077, 2001.

Phillips, O. L., Aragão, L. E. O. C., Lewis, S. L., Fisher, J. B., Lloyd, J., López-González, G., Malhi, Y., Monteagudo, A., Peacock, J., Quesada, C. A., Van Der Heijden, G., Almeida, S., Amaral, I., Arroyo, L., Aymard, G., Baker, T. R., Bánki, O., Blanc, L., Bonal, D., Brando, P., Chave, J., De Oliveira, Á. C. A., Cardozo, N. D., Czimczik, C. I., Feldpausch, T. R., Freitas, M. A., Gloor, E., Higuchi, N., Jiménez, E., Lloyd, G., Meir, P., Mendoza, C., Morel, A., Neill, D. A., Nepstad, D., Patiño, S., Peñuela, M. C., Prieto, A., Ramírez, F., Schwarz, M., Silva, J., Silveira, M., Thomas, A. S., Steege, H. Ter, Stropp, J., Vásquez, R., Zelazowski, P., Dávila, E. A., Andelman, S., Andrade, A., Chao, K. J., Erwin, T., Di Fiore, A., Honorio, E. C., Keeling, H., Killeen, T. J., Laurance, W. F., Cruz, A. P., Pitman, N. C. A., Vargas, P. N., Ramírez-Angulo, H., Rudas, A., Salamão, R., Silva, N., Terborgh, J., and Torres-Lezama, A.: Drought sensitivity of the amazon rainforest, Science, 323, 1344-1347, https://doi.org/10.1126/science.1164033, 2009.

Pons, T. L., Alexander, E. E., Houter, N. C., Rose, A., and Rijkers, T.: Ecophysiological Patterns in Guianan Forest Plants, in: Tropical forests of the Guiana shield: ancient forests in a modern world, edited by: Hammond, D., CABI Publishing, Wallingford, 195-231, 2005.

Poorter, L.: The relationships of wood-, gas- and water fractions of tree stems to performance and life history variation in tropical trees, Ann. Bot., 102, 367-375, https://doi.org/10.1093/aob/mcn103, 2008.
Poorter, L., McDonald, I., Alarcón, A., Fichtler, E., Licona, J. C., Peña-Claros, M., Sterck, F., Villegas, Z., and SassKlaassen, U.: The importance of wood traits and hydraulic conductance for the performance and life history strategies of 42 rainforest tree species, New Phytol., 185, 481-492, https://doi.org/10.1111/j.1469-8137.2009.03092.x, 2010.

Poveda, G. and Salazar, L. F.: Annual and interannual (ENSO) variability of spatial scaling properties of a vegetation index (NDVI) in Amazonia, Remote Sens. Environ., 93, 391-401, https://doi.org/10.1029/2001JD000717, 2004.

Powell, T. L., Wheeler, J. K., de Oliveira, A. A. R., da Costa, A. C. L., Saleska, S. R., Meir, P., and Moorcroft, P. R.: Differences in xylem and leaf hydraulic traits explain differences in drought tolerance among mature Amazon rainforest trees, Glob. Change Biol., 23, 4280-4293, https://doi.org/10.1111/gcb.13731, 2017.

Pratt, R. B. and Jacobsen, A. L.: Conflicting demands on angiosperm xylem: Tradeoffs among storage, transport and biomechanics, Plant Cell Environ., 40, 897-913, https://doi.org/10.1111/pce.12862, 2017.

Restrepo-Coupe, N., da Rocha, H. R., Hutyra, L. R., da Araujo, A. C., Borma, L. S., Christoffersen, B., Cabral, O. M. R., de Camargo, P. B., Cardoso, F. L., da Costa, A. C. L., Fitzjarrald, D. R., Goulden, M. L., Kruijt, B., Maia, J. M. F., Malhi, Y. S., Manzi, A. O., Miller, S. D., Nobre, A. D., von Randow, C., Sá, L. D. A., Sakai, R. K., Tota, J., Wofsy, S. C., Zanchi, F. B., and Saleska, S. R.: What drives the seasonality of photosynthesis across the Amazon basin? A cross-site analysis of eddy flux tower measurements from the Brasil flux network, Agr. Forest Meteorol., 182/183, 128-144, https://doi.org/10.1016/j.agrformet.2013.04.031, 2013.

Rice, A. H., Pyle, E. H., Saleska, S. R., Hutyra, L., Palace, M., Keller, M., De Camargo, P. B., Portilho, K., Marques, D. F., and Wofsy, S. C.: Carbon balance and vegetation dynamics in an old-growth Amazonian forest, Ecol. Appl., 14, 55-71, https://doi.org/10.1890/02-6006, 2004.

Richey, J. E., Nobre, C., and Deser, C.: Amazon river discharge and climate variability: 1903-1985, Science, 246, 101-103, https://doi.org/10.1126/science.246.4926.101, 1989.

Rifai, S. W., Girardin, C. A. J., Berenguer, E., Del Aguila-Pasquel, J., Dahlsjö, C. A. L., Doughty, C. E., Jeffery, K. J., Moore, S., Oliveras, I., Riutta, T., Rowland, L. M., Murakami, A. A., Addo-Danso, S. D., Brando, P., Burton, C., Ondo, F. E., DuahGyamfi, A., Amézquita, F. F., Freitag, R., Pacha, F. H., Huasco, W. H., Ibrahim, F., Mbou, A. T., Mihindou, V. M., Peixoto, K. S., Rocha, W., Rossi, L. C., Seixas, M., Silva-Espejo, J. E., Abernethy, K. A., Adu-Bredu, S., Barlow, J., da Costa, A. C. L., Marimon, B. S., Marimon-Junior, B. H., Meir, P., Metcalfe, D. B., Phillips, O. L., White, L. J. T., and Malhi, Y.: ENSO Drives interannual variation of forest woody growth across the tropics, Philos. T. R. Soc. Lond. B., 373, 20170410, https://doi.org/10.1098/rstb.2017.0410, 2018.

Roberts, J., Cabral, O. M. R., and Aguiar, L. F. De: Stomatal and Boundary-Layer Conductances in an Amazonian terra Firme Rain Forest, Br. Ecol. Soc., 27, 336-353, https://doi.org/10.2307/2403590, 1990.

Rowland, L., Lobo-do-Vale, R. L., Christoffersen, B. O., Mel??m, E. A., Kruijt, B., Vasconcelos, S. S., Domingues, T., Binks, O. J., Oliveira, A. A. R., Metcalfe, D., da Costa, A. C. L., Mencuccini, M., and Meir, P.: After more than a decade of soil moisture 
deficit, tropical rainforest trees maintain photosynthetic capacity, despite increased leaf respiration, Glob. Change Biol., 21, 46624672, https://doi.org/10.1111/gcb.13035, 2015a.

Rowland, L., da Costa, A. C. L. L., Galbraith, D. R., Oliveira, R. S., Binks, O. J., Oliveira, A. A. R. R., Pullen, A. M., Doughty, C. E., Metcalfe, D. B., Vasconcelos, S. S., Ferreira, L. V., Malhi, Y., Grace, J., Mencuccini, M., and Meir, P.: Death from drought in tropical forests is triggered by hydraulics not carbon starvation, Nature, 528, 119-122, https://doi.org/10.1038/nature15539, 2015 b.

Rowland, L., da Costa, A. C. L., Oliveira, A. A. R., Almeida, S. S., Ferreira, L. V., Malhi, Y., Metcalfe, D. B., Mencuccini, M., Grace, J., and Meir, P.: Shock and stabilisation following longterm drought in tropical forest from 15 years of litterfall dynamics, J. Ecol., 106, 1673-1682, https://doi.org/10.1111/13652745.12931, 2018.

Saatchi, S., Asefi-Najafabady, S., Malhi, Y., Aragao, L. E. O. C., Anderson, L. O., Myneni, R. B., and Nemani, R.: Persistent effects of a severe drought on Amazonian forest canopy, P. Natl. Acad. Sci. USA, 110, 565-570, https://doi.org/10.1073/pnas.1204651110, 2013.

Sala, A., Woodruff, D. R., and Meinzer, F. C.: Carbon dynamics in trees: Feast or famine?, Tree Physiol., 32, 764-775, https://doi.org/10.1093/treephys/tpr143, 2012.

Santiago, L. S., Goldstein, G., Meinzer, F. C., Fisher, J. B., Machado, K., Woodruff, D., and Jones, T.: Leaf photosynthetic traits scale with hydraulic conductivity and wood density in Panamanian forest canopy trees, Oecologia, 140, 543-550, https://doi.org/10.1007/s00442-004-1624-1, 2004.

Santiago, L. S., De Guzman, M. E., Baraloto, C., Vogenberg, J. E., Brodie, M., Hérault, B., Fortunel, C., and Bonal, D.: Coordination and trade-offs among hydraulic safety, efficiency and drought avoidance traits in Amazonian rainforest canopy tree species, New Phytol., 218, 1015-1024, https://doi.org/10.1111/nph.15058, 2018.

Santos, V. A. H. F. dos, Ferreira, M. J., Rodrigues, J. V. F. C., Garcia, M. N., Ceron, J. V. B., Nelson, B. W., and Saleska, S. R.: Causes of reduced leaf-level photosynthesis during strong El Niño drought in a Central Amazon forest, Glob. Change Biol., 24, 4266-4279, 2018.

Sayer, E. J., Powers, J. S., and Tanner, E. V. J.: Increased litterfall in tropical forests boosts the transfer of soil $\mathrm{CO}_{2}$ to the atmosphere, PLoS One, 2, 1-6, https://doi.org/10.1371/journal.pone.0001299, 2007.

Sendall, K. M., Vourlitis, G. L., and Lobo, F. A.: Seasonal variation in the maximum rate of leaf gas exchange of canopy and understory tree species in an Amazonian semi-deciduous forest, Brazil. J. Plant Physiol., 21, 65-74, https://doi.org/10.1590/S1677$04202009000100008,2009$.

Shuttleworth, W. J.: Evaporation from Amazonian Rainforest, Proc. R. Soc. Lond., 233, 321-346, 1988.

Skelton, R. P., West, A. G., and Dawson, T. E.: Predicting plant vulnerability to drought in biodiverse regions using functional traits, P. Natl. Acad. Sci. USA, 112, 5744-5749, https://doi.org/10.1073/pnas.1503376112, 2015.

Sobrado, M. A.: Aspects of tissue water relations and seasonal changes of leaf water potential components of evergreen and deciduous species coexisting in tropical dry forests, Oecologia, 68, 413-416, https://doi.org/10.1007/BF01036748, 1986.
Sombroek, W.: Spatial and Temporal Patterns of Amazon Rainfall, AMBIO A J. Hum. Environ., 30, 388-396, https://doi.org/10.1579/0044-7447-30.7.388, 2001.

Sotta, E. D., Meir, P., Malhi, Y., Nobre, A. D., Hodnett, M., and Grace, J.: Soil $\mathrm{CO}_{2}$ efflux in a tropical forest in the Central Amazon, Glob. Change Biol., 10, 601-617, https://doi.org/10.1111/j.1529-8817.2003.00761.x, 2004.

Stahl, C., Hérault, B., Rossi, V., Burban, B., Bréchet, C., and Bonal, D.: Depth of soil water uptake by tropical rainforest trees during dry periods: Does tree dimension matter?, Oecologia, 173, 11911201, https://doi.org/10.1007/s00442-013-2724-6, 2013a.

Stahl, C., Burban, B., Wagner, F., Goret, J.-Y., Bompy, F., and Bonal, D.: Influence of Seasonal Variations in Soil Water Availability on Gas Exchange of Tropical Canopy Trees, Biotropica, 45, 155-164, https://doi.org/10.1111/j.1744-7429.2012.00902.x, 2013b.

Sterck, F., Markesteijn, L., Toledo, M., Schieving, F., and Poorter, L.: Sapling performance along resource gradients drives tree species distributions within and across tropical forests, Ecology, 95, 2514-2525, https://doi.org/10.1890/13-2377.1, 2014.

Tadono, T., Nagai, H., Ishida, H., Oda, F., Naito, S., Minakawa, K., and Iwamoto, H.: Generation of the $30 \mathrm{M}-\mathrm{MESH}$ global digital surface model by alos prism, Int. Arch. Photogramm. Remote Sens. Spat. Inf. Sci. - ISPRS Arch., 41, 157-162, https://doi.org/10.5194/isprsarchives-XLI-B4-157-2016, 2016.

Tinoco-Ojanguren, C. and Pearcy, R. W.: Dynamic stomatal behavior and its role in carbon gain during lightflecks of a gap phase and an understory Piper species acclimated to high and low light, Oecologia, 92, 222-228, https://doi.org/10.1007/BF00317368, 1992.

Tobin, M. F., Lopez, O. R., and Kursar, T. A.: Responses of tropical understory plants to a severe drought: Tolerance and avoidance of water stress, Biotropica, 31, 570-578, https://doi.org/10.1111/j.1744-7429.1999.tb00404.x, 1999.

Tyree, M. T., Engelbrecht, B. M. J., Vargas, G., and Kursar, T. A.: Desiccation Tolerance of Five Tropical Seedlings in Panama. Relationship to a Field Assessment of Drought Performance, Plant Physiol., 132, 1439-1447, https://doi.org/10.1104/pp.102.018937, 2003.

Van Der Laan-Luijkx, I. T., Van Der Velde, I. R., Krol, M. C., Gatti, L. V., Domingues, L. G., Correia, C. S. C., Miller, J. B., Gloor, M., Van Leeuwen, T. T., Kaiser, J. W., Wiedinmyer, C., Basu, S., Clerbaux, C., and Peters, W.: Response of the Amazon carbon balance to the 2010 drought derived with CarbonTracker South America, Global Biogeochem. Cy., 29, 10921108, https://doi.org/10.1002/2014GB005082, 2015.

Van Der Werf, G. R., Randerson, J. T., Giglio, L., Gobron, N., and Dolman, A. J.: Climate controls on the variability of fires in the tropics and subtropics, Global Biogeochem. Cy., 22, GB3028, https://doi.org/10.1029/2007GB003122, 2008.

Veenendaal, E. M., Swaine, M. D., Agyeman, V. K., Blay, D., Abebrese, I. K., and Mullins, C. E.: Differences in Plant and Soil Water Relations in and Around a Forest Gap in West Africa during the Dry Season may Influence Seedling Establishment and Survival, J. Ecol., 84, 83-90, https://doi.org/10.2307/2261702, 1996.

Viechtbauer, W.: Package "metafor", R package version 2.0-0, 1262 available at: http://www.metafor-project.org/doku.php (last access: 13 February 2020), 2017. 
Vogt, U. K.: Hydraulic vulnerability, vessel refilling, and seasonal courses of stem water potential of Sorbus aucuparia L. and Sambucus nigra L., J. Exp. Bot., 52, 1527-1536, 2001.

Volaire, F.: A unified framework of plant adaptive strategies to drought: Crossing scales and disciplines, Glob. Change Biol., 24, 2929-2938, https://doi.org/10.1111/gcb.14062, 2018.

Wagner, F. H., Hérault, B., Bonal, D., Stahl, C., Anderson, L. O., Baker, T. R., Becker, G. S., Beeckman, H., Boanerges Souza, D., Botosso, P. C., Bowman, D. M. J. S., Bräuning, A., Brede, B., Brown, F. I., Camarero, J. J., Camargo, P. B., Cardoso, F. C. G., Carvalho, F. A., Castro, W., Chagas, R. K., Chave, J., Chidumayo, E. N., Clark, D. A., Costa, F. R. C., Couralet, C., da Silva Mauricio, P. H., Dalitz, H., de Castro, V. R., de Freitas Milani, J. E., de Oliveira, E. C., de Souza Arruda, L., Devineau, J.-L., Drew, D. M., Dünisch, O., Durigan, G., Elifuraha, E., Fedele, M., Ferreira Fedele, L., Figueiredo Filho, A., Finger, C. A. G., Franco, A. C., Freitas Júnior, J. L., Galvão, F., Gebrekirstos, A., Gliniars, R., Graça, P. M. L. D. A., Griffiths, A. D., Grogan, J., Guan, K., Homeier, J., Kanieski, M. R., Kho, L. K., Koenig, J., Kohler, S. V., Krepkowski, J., Lemos-Filho, J. P., Lieberman, D., Lieberman, M. E., Lisi, C. S., Longhi Santos, T., López Ayala, J. L., Maeda, E. E., Malhi, Y., Maria, V. R. B., Marques, M. C. M., Marques, R., Maza Chamba, H., Mbwambo, L., Melgaço, K. L. L., Mendivelso, H. A., Murphy, B. P., O’Brien, J. J., Oberbauer, S. F., Okada, N., Pélissier, R., Prior, L. D., Roig, F. A., Ross, M., Rossatto, D. R., Rossi, V., Rowland, L., Rutishauser, E., Santana, H., Schulze, M., Selhorst, D., Silva, W. R., Silveira, M., Spannl, S., Swaine, M. D., Toledo, J. J., Toledo, M. M., Toledo, M., Toma, T., Tomazello Filho, M., Valdez Hernández, J. I., Verbesselt, J., Vieira, S. A., Vincent, G., Volkmer de Castilho, C., Volland, F., Worbes, M., Zanon, M. L. B., and Aragão, L. E. O. C.: Climate seasonality limits leaf carbon assimilation and wood productivity in tropical forests, Biogeosciences, 13, 25372562, https://doi.org/10.5194/bg-13-2537-2016, 2016.

Williams, M., Malhi, Y., Nobre, A. D., Rastetter, E. B., Grace, J., and Pereira, M. G. P.: Seasonal variation in net carbon exchange and evapotranspiration in a Brazilian rain forest: A modelling analysis, Plant Cell Environ., 21, 953-968, https://doi.org/10.1046/j.1365-3040.1998.00339.x, 1998.

Williamson, G. B., Laurance, W. F., Oliveira, A. A., Delamônica, P., Gascon, C., Lovejoy, T. E., and Pohl, L.: Amazonian tree mortality during the 1997 El Nino drought, Conserv. Biol., 14, 15381542, https://doi.org/10.1046/j.1523-1739.2000.99298.x, 2000.

Wolfe, B. T.: Retention of stored water enables tropical tree saplings to survive extreme drought conditions, Tree Physiol., 37, 469480, https://doi.org/10.1093/treephys/tpx001, 2017.

Wolfe, B. T., Sperry, J. S., and Kursar, T. A.: Does leaf shedding protect stems from cavitation during seasonal droughts? A test of the hydraulic fuse hypothesis, New Phytol., 212, 1007-1018, https://doi.org/10.1111/nph.14087, 2016.

Wright, S. J. and van Schaik, C. P.: Light and the phenology of tropical trees, Am. Nat., 143, 192-199, https://doi.org/10.1086/285600, 1994.

Wright, S. J., Machado, J. L., Mulkey, S. S., and Smith, A. P.: Drought acclimation among tropical forest shrubs (Psychotria, Rubiaceae), Oecologia, 89, 457-463, https://doi.org/10.1007/BF00317149, 1992.
Wu, J., Albert, L. P., Lopes, A. P., Restrepo-Coupe, N., Hayek, M., Wiedemann, K. T., Guan, K., Stark, S. C., Christoffersen, B., Prohaska, N., Tavares, J. V., Marostica, S., Kobayashi, H., Ferreira, M. L., Campos, K. S., Dda Silva, R., Brando, P. M., Dye, D. G., Huxman, T. E., Huete, A. R., Nelson, B. W., and Saleska, S. R.: Leaf development and demography explain photosynthetic seasonality in Amazon evergreen forests, Science, 351, 972-976, https://doi.org/10.1126/science.aad5068, 2016.

Würth, M. K. R., Peláez-Riedl, S., Wright, S. J., and Körner, C.: Non-structural carbohydrate pools in a tropical forest, Oecologia, 143, 11-24, https://doi.org/10.1007/s00442-004-1773-2, 2005.

Yang, J., Tian, H., Pan, S., Chen, G., Zhang, B., and Dangal, S.: Amazon drought and forest response: Largely reduced forest photosynthesis but slightly increased canopy greenness during the extreme drought of 2015/2016, Glob. Change Biol., 24, 1919-1934, https://doi.org/10.1111/gcb.14056, 2018 a.

Yang, Y., Guan, H., Batelaan, O., McVicar, T. R., Long, D., Piao, S., Liang, W., Liu, B., Jin, Z., and Simmons, C. T.: Contrasting responses of water use efficiency to drought across global terrestrial ecosystems, Sci. Rep., 6, 1-8, https://doi.org/10.1038/srep23284, 2016.

Yang, Y., Saatchi, S. S., Xu, L., Yu, Y., Choi, S., Phillips, N., Kennedy, R., Keller, M., Knyazikhin, Y., and Myneni, R. B.: Post-drought decline of the Amazon carbon sink, Nat. Commun., 91, 3172, https://doi.org/10.1038/s41467-018-05668-6, 2018 b.

Zanchi, F. B., Meesters, A. G. C. A., Waterloo, M. J., Kruijt, B., Kesselmeier, J., Luizão, F. J., and Dolman, A. J.: Soil $\mathrm{CO}_{2}$ exchange in seven pristine Amazonian rain forest sites in relation to soil temperature, Agr. Forest Meteorol., 192/193, 96-107, https://doi.org/10.1016/j.agrformet.2014.03.009, 2014.

Zanne, A. E., Lopez-Gonzalez, G., Coomes, D. A. A., Ilic, J., Jansen, S., Lewis, S. L. S. L., Miller, R. B. B., Swenson, N. G. G., Wiemann, M. C. C., and Chave, J.: Global wood density database, Dryad, 235, 33, https://doi.org/10.5061/dryad.234, 2009.

Zemp, D. C., Schleussner, C. F., Barbosa, H. M. J., Van Der Ent, R. J., Donges, J. F., Heinke, J., Sampaio, G., and Rammig, A.: On the importance of cascading moisture recycling in South America, Atmos. Chem. Phys., 14, 13337-13359, https://doi.org/10.5194/acp-14-13337-2014, 2014.

Zemp, D. C., Schleussner, C. F., Barbosa, H. M. J., and Rammig, A.: Deforestation effects on Amazon forest resilience, Geophys. Res. Lett., 44, 6182-6190, https://doi.org/10.1002/2017GL072955, 2017.

Zhou, S., Duursma, R. A., Medlyn, B. E., Kelly, J. W. G., and Prentice, I. C.: How should we model plant responses to drought? An analysis of stomatal and non-stomatal responses to water stress, Agr. Forest Meteorol., 182/183, 204214, https://doi.org/10.1016/j.agrformet.2013.05.009, 2013.

Ziemińska, K., Rosa, E., Gleason, S., and Holbrook, N. M.: Wood capacitance is related to water content, wood density, and anatomy across 30 temperate tree species, bioRxiv, 772764, https://doi.org/10.1101/772764, 2019. 